\title{
The Circulation of Pragmatic Normative Literature in Spanish America (16th-17th Centuries)
}

\author{
Otto Danwerth
}

\section{Introduction}

By the third decade of the 16th century, in the wake of the conquests of Mexico and Peru, the Spanish monarchy was confronted with the task of establishing its dominion over huge populations and across vast distances in Central and South America, albeit with limited human and material resources. In light of the scarcity and the remoteness, great importance was accorded to propagating and implementing codes of conduct - not just among European settlers, but also over the indigenous population.

Which norms and mediatic forms had been put to service by the Spanish sovereign and colonial authorities to regulate codes of conduct in early colonial Spanish America? As set out in Thomas Duve's introductory chapter, the contributors of this volume are exploring the presence and functions of a particular type of normative literature in Ibero-America. To a lesser degree we draw on conventional sources of legal history, i.e., the large stacks of textual collections pertaining to the norm-setting practices of higher authorities or other early modern legal sources from the Castilian tradition and the ius commune. Instead, close attention is paid to modalities of normativity addressed to 'practitioners', especially religious ones (such as parish priests or missionaries), and, in particular, we take into consideration sources from the field of moral theology. ${ }^{1}$

As explained in the first chapter, the use of the term 'pragmatic normative literature' was partly inspired by a pioneering work of legal historiography written in the second half of the 19th century. In his History of Popular Literature of Roman Canon Law in Germany at the End of the 15th and at the Beginning of the 16th Century (1867), ${ }^{2}$ Roderich Stintzing treated diverse types of juridical literature, which had been neglected by the legal historians of his

\footnotetext{
1 For the multi-normative order constituted by canon law and moral theology in the 16th century, see Duve, "Katholisches Kirchenrecht und Moraltheologie im 16. Jahrhundert".

2 Stintzing, Geschichte der populären Literatur des römisch-kanonischen Rechts in Deutschland.
}

(C) OTTO DANWERTH, 2020 | DOI:10.1163/9789004425736_004

This is an open access chapter distributed under the terms of the CC-BY-NC 4.o license.o Danwerth - 9789004425736 
time. Sources such as alphabetical collections, instructions on legal procedure, notarial handbooks, compendia of cases, or "ecclesiastical jurisprudence" like summae confessorum, and small treatises on confession are good examples of 'pragmatic normative literature', as defined by Duve.

Similar genres have not been considered as particularly relevant sources by legal historians of early colonial Ibero-America, either. We argue, instead, that 'pragmatic normative literature' - especially from the religious field - held a greater significance in the remote frontier contexts of an early modern empire. This is in no small part due to the fact that such a body of literature did not represent complex instructions or a sophisticated normative framework, but instead condensed normative knowledge. These texts were perceived as 'weak' given their lack of theoretical complexity compared to erudite scholarly treatises. They were 'strong', however, in a pragmatic sense, as their flexible normative underpinnings enabled them to take up those notions of legitimacy that became a part of the moral economy of the colonial society. Not least in the imperial peripheries, these adaptable pragmatic texts - catechisms, manuals for confession, moral theological instructions, but as well sermonarios and devocionarios - became particularly important. ${ }^{3}$ Even in places where the reach of law was limited, the practice of regulations and notions of 'proper' behaviour were mediated through ecclesiastical institutions and actors, but also through religious symbols and practice.

\section{Circulation of Books in Colonial Spanish America: Relevant} Features

In order to examine the presence and function of pragmatic normative literature in Spanish America during the 16th and 17th centuries, it is crucial to explore the circulation and distribution of these material resources - mainly books but as well other mediatic forms. The aim of this chapter is to sketch out central aspects of the topic, to offer a historiographic synthesis and to discuss some empirical evidence. Painting in broad strokes, as it were, we will proceed in two steps: First, some basic information about book circulation in colonial Spanish America (sources, historiography, numbers) will be provided. In a second step, a few cases based on the literature and on archival sources will be

3 For a brief typology, see Resines Llorente, Catecismos americanos del siglo XVI, vol. 1, 20-21. Saranyana (ed.), Teología en América Latina, vol. 1, provides an introduction to some of these sources, which are dealt with in detail in the following chapters of the present volume. 
discussed, which might illustrate how the circulation of pragmatic literature in Mexico and Peru can be traced, reconstructed and analysed.

\subsection{The Transatlantic Book Trade as a Knowledge Regime}

The transatlantic book trade from Seville to the New World was a key factor. The Castilian Crown and its institutions established a system of controlled exportation and circulation of books in its territories. This can be construed as a "knowledge regime", i.e., "the structured and (more or less) stabilised interrelation of practices, rules, principles and norms concerning knowledge and different forms of knowledge". 4 One might distinguish two dimensions of knowledge regimes: First, the regulation of the relationship between different forms of knowledge (e.g., between scientific and non-scientific, or erudite and pragmatic knowledge); second, the regulation of knowledge production, distribution, and use by 'external' factors, e.g., political and juridical frameworks, cultural traditions, or technical infrastructures. ${ }^{5}$

In the second sense, at least, our topic is a case in point. The Casa de la Contratación (House of Trade) was founded in 1503 in Seville to control navigation, commerce, and migration to the Indies. It aimed to regulate all traffic coming to Spanish America, including ships, goods, and people. ${ }^{6}$ Furthermore, the Casa held jurisdiction in commercial matters (with judges and a prison), and it was acknowledged as being a centre of nautical and cartographic knowledge.

Books had to be registered prior to being exported since they were an ambivalent resource: ${ }^{7}$ sources of knowledge that at the same time could spread supposedly 'dangerous' Protestant or other heretical ideas to the overseas territories. ${ }^{8}$ There are no extant detailed book lists for the first half of the 16th century in the House of Trade's records. In 1550, a royal order issued by Emperor Charles $\mathrm{v}$ decreed that each of the books to be exported to the New World was to be mentioned individually in the records - and no longer "en bulto", i.e., in a

4 Wehling, "Wissensregime", 704 (translation, OD).

5 Wehling, "Wissensregime", 704.

6 The classic - and 'pragmatic' - manual about the Trade House is Veitia Linage, Norte de la Contratación de las Indias occidentales, first published in Sevilla in 1672. For literature on this topic, see García-Baquero, La Carrera de Indias: Suma de contratación y océano de negocios; Acosta Rodríguez, González Rodríguez and Vila Vilar (eds.), La Casa de la Contratación y la navegación entre España y las Indias.

7 See Danwerth et al., "Resources in a Social World", 234-236.

8 See González Sánchez, New World Literacy, 54-57. The Spanish version of this book was published in 1999 under the title Los mundos del libro. Medios de difusión de la cultura occidental en las Indias de los siglos XVI $y$ XVII, Sevilla. 
lot. ${ }^{9}$ However, only with the publication of Gaspar de Quiroga's Index of Prohibited Books in $1583,{ }^{10}$ was this norm complied with more regularly for approximately the next 40 years, so that more homogeneous book lists were issued. From 1620, fiscal reasons made it unnecessary to specify the correct content of boxes to be exported, and from around 166o detailed registers of books become less frequent in the documentation (figure 3.1). ${ }^{11}$ These conditions might explain why especially the last two decades of the 16th century have still a great deal of source material to be examined. To this end our archival work about the export of books concentrates on ship registers from the late 16th and early 17th centuries, which are conserved in the Archivo General de Indias (AGI).

In order to prevent the transit of incriminated texts included in the Index of Prohibited Books, the Casa de la Contratación cooperated with the Inquisition. Its officials, residing in the castle of Triana, had to approve the cargo lists. $^{12}$ For that purpose, evaluators were appointed: friars of different orders, in general Franciscans and Dominicans. ${ }^{13}$ The cooperation between the House of Trade and the Holy Office was not without tension, though; furthermore, the inquisitorial censors did not always perform rigid examinations of the book lists. As research has shown, the controls were quite lax during certain periods, when lists were only checked but not compared against the actual books in the boxes. Thus the knowledge regime became permeable, both in Seville and in fact also in the American harbours, given that the inspections of the recently arrived ships was not always conducted in a rigorous manner either.

\subsection{A Historiographic Sketch of Book Circulation in Early Modern Spanish America}

The historiography about the circulation of books in Spanish America during early modern times has its roots in the 19th century. A brief survey of this rich but disperse tradition might be at hand since our work draws strongly on some historiographic contributions. After the Independence period, Latin American scholars in the second half of that century were collecting and

Recopilación de leyes de los reynos de las Indias, lib. I, tít. XXIV, ley v: "De los libros que se imprimen y pasen a las Indias"; see ley viI as well. Cf. González Sánchez, New World Literacy, $5^{\mathrm{O}}-51$.

10 Bujanda, Index de l'Inquisition espagnole 1583, 1584.

11 See González Sánchez, New World Literacy, 47-53.

12 With regard to this institutional cooperation, see Rueda Ramírez, Negocio e intercambio cultural, $61-8$ o. The rest of this paragraph follows his analysis.

13 For example: Petition and license by the Inquisition for books to be sent to Mexico City, Sevilla, 26/27-II-1705, AGI, Contratación 674, no. 2, fols. 241r, 242r; and more licenses in the same legajo. 


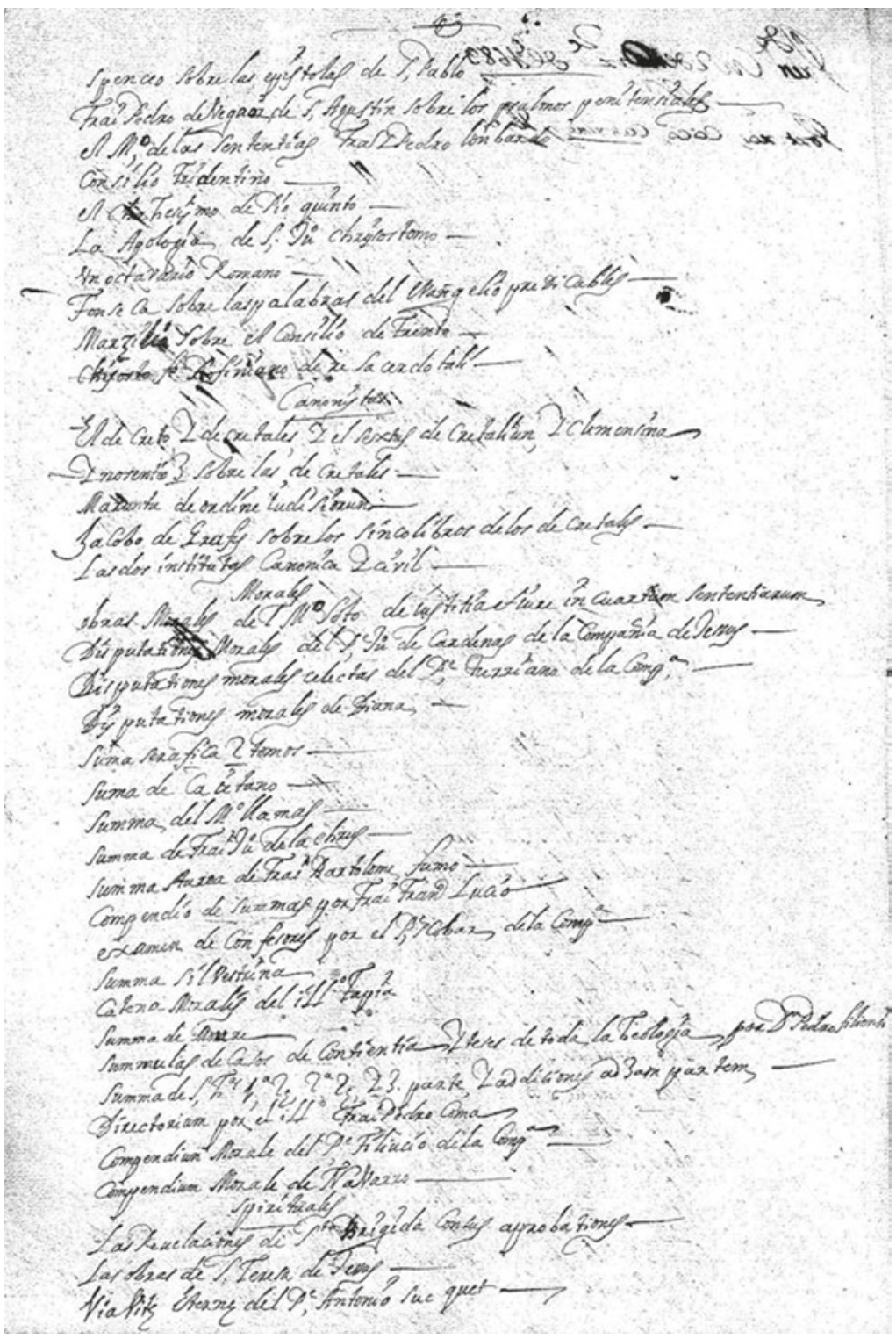

FIGURE 3.1 Ship register with book list "para su venta en los reinos de las Indias", issued by Don Francisco Joseph de la Estrella, priest from Sevilla, indicating book categories (“Canonistas", “Morales”), Sevilla, 2-XII-1689, AG I, Contratación 674, no. 1 , fols. $104 \mathrm{r}-105 \mathrm{~V}$, here fol. $104 \mathrm{~V}$ 
composing bibliographic works about the intellectual outputs of their new countries in early modern times. This documentation should be set in the context of nation-building processes, which were accompanied by quite negative depictions of Spanish "repressive" rule in the colonial past. ${ }^{14}$ The most eminent representative of that formative period was the Chilean scholar José Toribio Medina (1852-1930), who, among other topics, cultivated the research on Spanish American - and not only regional or national - bibliography. One should mention his books on the American printing presses and the Biblioteca Hispano-Americana (1493-1810), still reference works. ${ }^{15}$

A new generation of researchers, working between the 1930s and 1950s, added fresh evidence and offered new interpretations on the circulation of books in America. ${ }^{16}$ They took into consideration the institutional context of transatlantic book trade and found important empirical data in their respective regional as well as in Spanish archives, basing their results on new types of sources: ship registers, contracts, inquisitorial records, etc. Thus, they contested traditional assumptions (e.g., on the effectivity of the inquisitorial control) and highlighted instead the volume of the transatlantic book trade.

In that period, historians from different fields like Edmundo O'Gorman, Guillermo Lohmann Villena, Rubén Vargas Ugarte, Guillermo Furlong Cardiff, Carlos Luque Colombres, Vicente Osvaldo Cutolo, and Javier Malagón Barceló contributed to the field. ${ }^{17}$ However, two scholars published landmark books on the topic: the Argentinian José Torre Revello (El libro, la imprenta y el periodismo en América durante la dominación española $)^{18}$ and the U.S. American Irving Leonard, whose opus magnum Books of the Brave appeared in 1949. ${ }^{19}$ Among

14 Calvo, "The politics of print", 280.

15 Medina, Biblioteca hispano-americana (1493-1810); plus many works focusing on each of the diverse printing centres. Another landmark work was published posthumously: Medina, Historia de la imprenta en los antiguos dominios españoles de América y Oceanía. Cf. Calvo, "The politics of print", 281.

16 See Calvo, "The politics of print", $282-283$, who cites two important contributions of the early 2oth century: Rodríguez Marín, El "Quijote" y don Quijote en América; Fernández del Castillo (ed.), Libros y libreros en el siglo XVI.

17 O'Gorman, "Bibliotecas y librerías coloniales, 1585-1694"; Lohmann Villena, "Los libros españoles en Indias”; Vargas Ugarte, Impresos peruanos; Furlong Cardiff, Bibliotecas argentinas durante la dominación hispánica; Luque Colombres, "Libros de Derecho en bibliotecas particulares cordobesas (1573-1810)"; Osvaldo Cutolo, "Bibliotecas jurídicas en el Buenos Aires del siglo XVII"; Malagón Barceló, La literatura jurídica española del siglo de oro en la Nueva España.

18 Torre Revello, El libro, la imprenta y el periodismo en América durante la dominación española; see as well his posterior work, e.g., Torre Revello, "Lecturas indianas (siglos XVI-XVIII)".

19 Leonard, Books of the Brave. 
the articles collected in this classic work, some traced the presence of books that, according to the older historiography, were not supposed to be found in colonial Spanish America, such as picaresque novels or Don Quixote. ${ }^{20}$ Other contributions, more relevant to our subject, dealt with the book trade in Lima and Mexico, and with their 'bestsellers' in the late 16th century.

The most recent wave of research on our topic started in the late 1980 s. $^{21}$ In addition to the publication of several comprehensive works, a renaissance of historical book studies can be observed over the past three decades or so in many Latin American countries and in Spain. We can now consult quite a number of book histories for specific countries and overviews of regional research. Moreover, good editions of book inventories are available, mainly issued by individuals from the colonial elites (including Spanish officials, noblemen, clerics, encomenderos, and caciques), and several by institutions. The majority of these studies are dedicated to the former centres of the viceroyalties New Spain and Peru. Especially in Mexico, investigators open the field of book history to wider issues like literacy, education, and reading. ${ }^{22}$

Not meant as an exhaustive list, the following authors might be mentioned as exemplary figures for the regional historiographies (on the 16th-17th centuries) of the recent decades:

- the Caribbean area: Juan José Sánchez Baena, Ambrosio Fornet;23

- New Spain: Javier Barrientos Grandón, Alejandro Mayagoitía, W. Michael Mathes, Magdalena Chocano, Carmen Castañeda, Idalia García, Norah Jiménez, Kenneth Ward;24

$20 \quad$ See Calvo, "The politics of print", 283.

21 A precursor of that wave was Millares Carlo, "Bibliotecas y difusión del libro en Hispanoamérica colonial". See as well Solano, "Fuentes para la historia cultural: Libros y bibliotecas de la América colonial”; and the exhibition catalogue edited by Greer Johnson, The Book in the Americas.

22 See Calvo, "The politics of print", 286-287; González Sánchez, New World Literacy, 30-32.

23 Sánchez Baena, "Noticias sobre el mundo del libro en Cuba antes del desarrollo de la imprenta (1525-1763)"; Fornet, El libro en Cuba, siglos XVIII y XIX. See as well Hampe Martínez, "Lecturas de un jurista del siglo XVI".

24 Barrientos Grandón, La cultura jurídica en la Nueva España; Mayagoitía, "Notas sobre los alegatos impresos novohispanos"; Mathes, "Humanism in Sixteenth and Seventeenth Century Libraries of New Spain"; Chocano Mena, "Colonial Printing and Metropolitan Books"; Castaneda, Del autor al lector. Historia del libro en México; García Aguilar, "El conocimiento histórico del libro y la biblioteca novohispanos”; García Aguilar and Rueda Ramírez (eds.), Leer en tiempos de la colonia; Jiménez, "Cuentas fallidas, deudas omnipresentes"; Ward, "Mexico, where they coin money and print books". See as well Garone Gravier, "Fuentes para el estudio de la tipografía, la imprenta y el libro antiguo mexicano (1539-1821)”; Luque Talaván, “De los libros surgen las leyes”; Cervantes Bello (ed.), Libros y Lectores en las sociedades hispanas: España y Nueva España (Siglos XVI-XVIII). 
- Central America: Pedro Rueda Ramírez; ${ }^{25}$

- New Granada: Ildefonso Leal, José del Rey Fajardo, Mónica Fortich Navarro; ${ }^{26}$

- Peru: Teodoro Hampe Martínez, Carlos Alberto González Sánchez, Pedro Guibovich, Herman Nébias Barreto; ${ }^{27}$

- Charcas: Daisy Rípodas Ardanaz, Josep Barnadas, Marcela Inch; ${ }^{28}$

- the Río de la Plata and interior regions: Daisy Rípodas Ardanaz, Marcela Aspell, Ernesto Maeder, Alejandro Parada, Esteban Llamosas, Silvano Benito Moya, Celina Lértora Mendoza; ${ }^{29}$ and

- Chile: Bernardo Bravo Lira, Javier Barrientos Grandón, Carlos Salinas Araneda. ${ }^{30}$

We should not forget important studies coming from Spain. Of special interest are the authors of what might be labelled 'Seville school of book history'. Following the lead of León Carlos Alvarez Santaló and the late Hispanist Klaus Wagner, early modern historians like Carlos Alberto González Sánchez, Pedro Rueda Ramírez, and Natalia Maillard have contributed widely to our

25 Rueda Ramírez, "Libros europeos en Centroamérica en los siglos XVI-XVII". For the 18th and 19th centuries, with respect to Costa Rica, see Molina Jiménez, El que quiera divertirse.

26 Leal, Libros y bibliotecas en Venezuela colonial (1633-1767); Rey Fajardo, Las bibliotecas jesuíticas en la Venezuela colonial; Rey Fajardo and Marín Cortés (eds.), La biblioteca colonial de la Universidad Javeriana comentada; Fortich Navarro, Togados y letrados; CórdobaRestrepo (ed.), Biblioteca antigua. Circulación y conocimiento. See as well, in this volume, Pilar Mejía's chapter 10 with reference to Cartagena de Indias.

27 Hampe Martínez, Bibliotecas privadas en el mundo colonial; Hampe Martínez, "Las bibliotecas virreinales en el Perú y la difusión del saber italiano"; González Sánchez, "La cultura del libro en el Virreinato del Perú en tiempos de Felipe II"; Guibovich Pérez, "The Printing Press in Colonial Peru"; Nébias Barreto, "Legal Culture and Argumentation in the ViceReign of Peru from the 16 th to the 18 th centuries". See as well Dolezalek, "Libros jurídicos anteriores a 1800 en la Biblioteca de la Universidad Nacional Mayor de San Marcos en Lima".

28 Rípodas Ardanaz, "Bibliotecas privadas de funcionarios de la Real Audiencia de Charcas"; Barnadas, Bibliotheca Boliviana Antiqva; Inch C., "La Biblioteca Potosina de la Compañía de Jesús".

29 Rípodas Ardanaz, "Libros, bibliotecas y lecturas [cap. 22]"; Aspell de Yanzi Ferreira and Page (eds.), La Biblioteca Jesuítica de la Universidad Nacional de Córdoba; Maeder, "Libros, bibliotecas, control de lecturas e imprentas rioplatenses en los siglos XVI al XVIII"; Parada, "Tipología de las bibliotecas Argentinas desde el periodo hispánico hasta 1830"; Llamosas, "Probabilismo, probabiliorismo y rigorismo"; Benito Moya, "Bibliotecas y libros en la cultura universitaria de Córdoba durante los siglos XVII y XVIII”; Lértora Mendoza, "Bibliotecas académicas coloniales".

30 Bravo Lira, "La literatura jurídica indiana en el Barroco"; Barrientos Grandón, La cultura jurídica en el Reino de Chile; Salinas Araneda, "Los textos utilizados en la enseñanza del Derecho Canónico en Chile indiano". See as well Argouse, "De libros y otras cosas". 
understanding of book circulation in Spain and in the Atlantic world. ${ }^{31}$ Their work sheds new light on the commercial networks and the intermediaries (booksellers, merchants) involved. Moreover, there are very good book histories and related issues about the Iberian Peninsula, which further our understanding of the Ibero-American perspective. ${ }^{32}$

Apart from the studies cited above treating major spaces within early modern Ibero-America - other regions have not received as much attention, like former frontier areas or Portuguese America ${ }^{33}$ - we have at our disposal a good deal of legal historical scholarship on printing and the commerce of books in Castilian law and Derecho Indiano. ${ }^{34}$

After sketching this historiographic background, let us now turn to some of the already mentioned types of sources most relevant for the study of book circulation. They will be discussed following the movement of books from Europe to America.

31 For a few of the most recent contributions, see González Sánchez, Atlantes de papel; González Sánchez, "La cultura escrita en el Mundo Atlántico colonial”; González Sánchez, "El comercio de libros entre Europa y América en la Sevilla del siglo XVI”; Rueda Ramírez, Negocio e intercambio cultural; Rueda Ramírez, "El comercio de libros en Latinoamérica colonial”; Rueda Ramírez (ed.), El libro en circulación en el mundo moderno en España y Latinoamérica; García Aguilar and Rueda Ramírez (eds.), El libro en circulación en la América colonial; Maillard Alvarez, "Aproximación a la creación de las redes de distribución de libros en América"; Maillard Alvarez (ed.), Books in the Catholic World during the Early Modern Period.

32 See, for example, Cátedra and López-Vidriero (eds.), La memoria de los libros; Wilkinson (ed.), Iberian Books; Wilkinson and Lorenzo (eds.), Iberian Books; Wilkinson and Lorenzo (eds.), A Maturing Market; Peñalver Gómez (ed.), América escrita. On the history of a printer dynasty important for the establishment of the printing press in Mexico, see Griffin, The Crombergers of Seville. With respect to Portugal, see the monographic issue $O$ livro antigo em Portugal e Espanha, séculos XVI-XVIII; Ramada Curto (ed.), Bibliografia da História do Livro em Portugal, séculos XV-XIX; Camarinhas, "Bibliotecas particulares de magistrados no século XVIII"; Palomo, "Anaqueles de sacra erudición"; Guedes de Campos, Para se achar facilmente o que se busca; Giurgevich and Leitão, Clavis bibliothecarum.

33 See only Moraes, Livros e bibliotecas no Brasil colonial; Grover, "The Book and the Conquest"; González Sánchez, "La cultura escrita en el Mundo Atlántico colonial", Agnolin, Linvenzione del Tupi; as well as Gustavo Machado Cabral (Chapter 5) in this volume.

34 See Mohler, "Publishing in colonial Spanish America"; Ávila Martel, "La impresión y circulación de libros en el derecho indiano"; Tau Anzoátegui, Nuevos Horizontes en el estudio histórico del Derecho Indiano, ch. 5 ("El libro jurídico"), 70-84; Tau Anzoátegui, El Jurista en el Nuevo Mundo, 14-16; Reyes Gómez, El libro en España y América. 


\subsection{The Exportation of Pragmatic Books to the New World}

Despite the restrictions mentioned above and the control mechanisms exercised by civil and ecclesiastical authorities, the transatlantic book trade was a flourishing enterprise. It is estimated that up to $85 \%$ of the books circulating in America were imported and of European origin. ${ }^{35}$ Of these imported works, the great majority had been printed in Spain, with very few having been printed in other European centres of book-production (France, Flanders, Italy, Portugal, Holy Roman Empire) before arriving in Seville.

The itinerary of the books on the ocean followed the 'Carrera de Indias'. In order to better protect the ships against pirates, a convoy system was established from 1564 onward, with two fleets per year heading for New Spain (Veracruz) and Tierra Firme (Nombre de Dios and Cartagena). Due to the fast growing immigration to Spanish America, the market for books was expanding. In comparison to other goods and merchandise exported from Seville, however, books constituted only a very small portion of the cargo; some researchers calculate that their percentage amounted to $2 \%$, on average. ${ }^{36}$

The ship registers kept in the Archivo General de Indias (AGI, Seville) are a central type of source for tracing European books to the New World. Although they were usually studied by economic historians (think, for example, of Pierre Chaunu's work), some 'modern classical' researchers of book history, like Leonard and Torre Revello, already consulted these sources in the middle of the 2oth century. In 1973, Helga Kropfinger von Kügelgen dedicated a concise and dense monograph to the complete export lists of books sent to New Spain in one year: $1586 .{ }^{37}$

The analysis of the ship registers provides us with high percentages of religious literature and respective categories; some scribes even organised the lists according to the book sizes (from folio to quarto and octavo). ${ }^{38}$

Carlos Alberto González Sánchez has analyzed the entire book lists for the years $1583^{-1584}$ (824 books) and the year 1605 (2098 books). Summing up his findings very briefly, we can state that the percentage of religious books in the

35 See Hampe Martínez, "Historiografía del libro en América hispana", 61.

36 See González Sánchez, New World Literacy, 96.

37 Kropfinger von Kügelgen, Exportación de libros europeos de Sevilla a la Nueva España en el año de 1586.

38 Ship register with list of books to be sent to New Spain, issued by Fernando Romero y Torres, vecino of Seville, indicating category and size of books ("Libros de q[uar] to theologuicos", "Juridicos de fol[io]"), Seville, 23-VI-1689, AGI, Contratación 674, no. 1, fols. $64 \mathrm{r}-72 \mathrm{r}$, here fol. 65v; Ship register with list of books "para su venta en los reinos de las Indias", issued by Don Francisco Joseph de la Estrella, presbítero en Sevilla, indicating category of books ("Canonistas", "Morales"), Sevilla, 2-XII-1689, AGI, Contratación 674, no. 1 , fols. 104r-105v, here fol. 104v (see figure 3.1). 
samples rose from $34 \%$ in the 158 os to $77 \%$ in 1605 . He divides the religious books into the following genres: ${ }^{39}$

Types Per cent of religious books

\begin{tabular}{lcc}
\hline & $\mathbf{1 5 8 3 - 8 4}$ & $\mathbf{1 6 0 5}$ \\
\hline Spiritual & 24.6 & 47.8 \\
Theology & $\mathbf{2 2 . 8}$ & 9.6 \\
Prayer and liturgy & 20.3 & 32 \\
Moral theology & 20 & 1.8 \\
Canon law & 5 & 0.1 \\
Oratory & 4.6 & 2 \\
Hagiography & 3.5 & 6.8 \\
\hline
\end{tabular}

While we cannot refer here to the author's discussions of the works mentioned, we would nevertheless like to stress two points. First, the best-selling author among the spiritual literature was the Dominican Fray Luis de Granada (e.g., Libro de la oración y de la meditación). Secondly, regarding manuals of moral theology, González Sánchez' analysis is quite insightful:

The most numerous are the Suma de casos morales by Bartolomé de Medina, with nineteen copies, and the very successful Suma de casos de conciencia by the Franciscan Manuel Rodríguez, with fifteen copies. But the most widely distributed was undoubtedly the Summario by Martín de Azpilcueta, a disciple of Domingo de Soto, of which I have counted only seven. Others, also widely accepted, were those by Antonio de Córdoba, Juan de Pedraza, and Tomás de Mercado. A special case, with eighteen copies, is the Director [i] um curatorum of the Dominican Bishop of Elna, Pedro Martír Coma, a book that is everywhere in ecclesiastical libraries, and that is not a manual of morality in the strict sense, but rather a text aimed at forming priests, though with continual allusions to confession and ethical problems. ${ }^{40}$

This quote shows that detailed reconstructions of book lists might provide clues for contextualising Azpilcueta's work in the second half of the 16th

39 González Sánchez, New World Literacy, 100.

40 González Sánchez, New World Literacy, 112. 
century. ${ }^{41}$ Pedro Rueda, in his profound analysis of book trade during the first half of the 17th century, has demonstrated that 'el Navarro', as Azpilcueta was also known, can be found in many exportation documents (figure 3.2). However, other authors of Sumas morales were registered more frequently in that period, such as Manuel Rodríguez or Pedro de Ledesma. ${ }^{42}$

\subsection{Books Stemming from American Printing Presses}

Although the great majority of the books circulating in America were imported via Seville, about $15 \%$ were printed in the overseas territories. These books were supplied by the few printing presses that had received a royal license in Spanish America: they operated in Mexico City (1539), Lima (1581/1584), Puebla (1640), and Guatemala (166o). In the remaining areas of the vast region called las Indias, only from the 18th century onward, printing centres were established, for example, in Havana (1707), Santafé de Bogotá (1736), Quito (1759) and Buenos Aires (1780), followed by Caracas in $1808 .{ }^{43}$

As the printing presses of Mexico and Lima had been explicitly installed to help missionaries in their activities, it should not come as a surprise to find among their production a great many of catechetic books (catecismos, doctrinas), confessionaries and sermonaries, including translations into indigenous languages and vocabularies. ${ }^{44}$ Think, for example, of the pre-Tridentine Confessionario mayor en lengua Mexicana y Castellana by the Franciscan friar Alonso de Molina (Mexico 1565), ${ }^{45}$ or of the voluminous 'pastoral texts' published in

41 The Manual de confessores y penitentes written by this canon lawyer and moral theologian is examined by Manuela Bragagnolo (Chapter 6) in this volume.

42 Rueda Ramírez, Negocio e intercambio cultural, 309-312.

43 A classic is Medina, Historia de la imprenta en los antiguos dominios españoles de América y Oceanía. See as well Thompson and Woodbridge, Printing in Colonial Spanish America; Maris Fernández, La imprenta en Hispanoamérica; Deylen, "Buchdruck, kolonialer, in Lateinamerika". There is abundant literature on the history of imprints in the various American publishing centers. For Mexican literature, just see García Icazbalceta, Bibliografía mexicana del siglo XVI ( $1^{\text {a }}$ ed. 1886); Zulaica Gárate, Los franciscanos y la imprenta en México en el siglo XVI. For Peru, see Vargas Ugarte, Impresos peruanos.

44 See, for example, Resines Llorente, Catecismos americanos del siglo XVI; Durán, Monumenta catechética hispanoamericana (siglos XVI-XVIII); Gil, Primeras "doctrinas" del Nuevo Mundo; Jiménez, "Los libros en lenguas indígenas como un género de las imprentas novohispanas entre los siglos XVI y XVII"; Guibovich Pérez, "The Printing Press in Colonial Peru".

45 Molina, Confessionario mayor en lengua Mexicana y Castellana. See Saranyana (ed.), Teología en América Latina, vol. 1, 55-59; Durán, Monumenta catechética hispanoamericana, vol. 1, 353-541. For pre-Tridentine catechisms edited by bishop Juan de Zumárraga in Mexico, see José Luis Egío (Chapter 7) in this volume. 


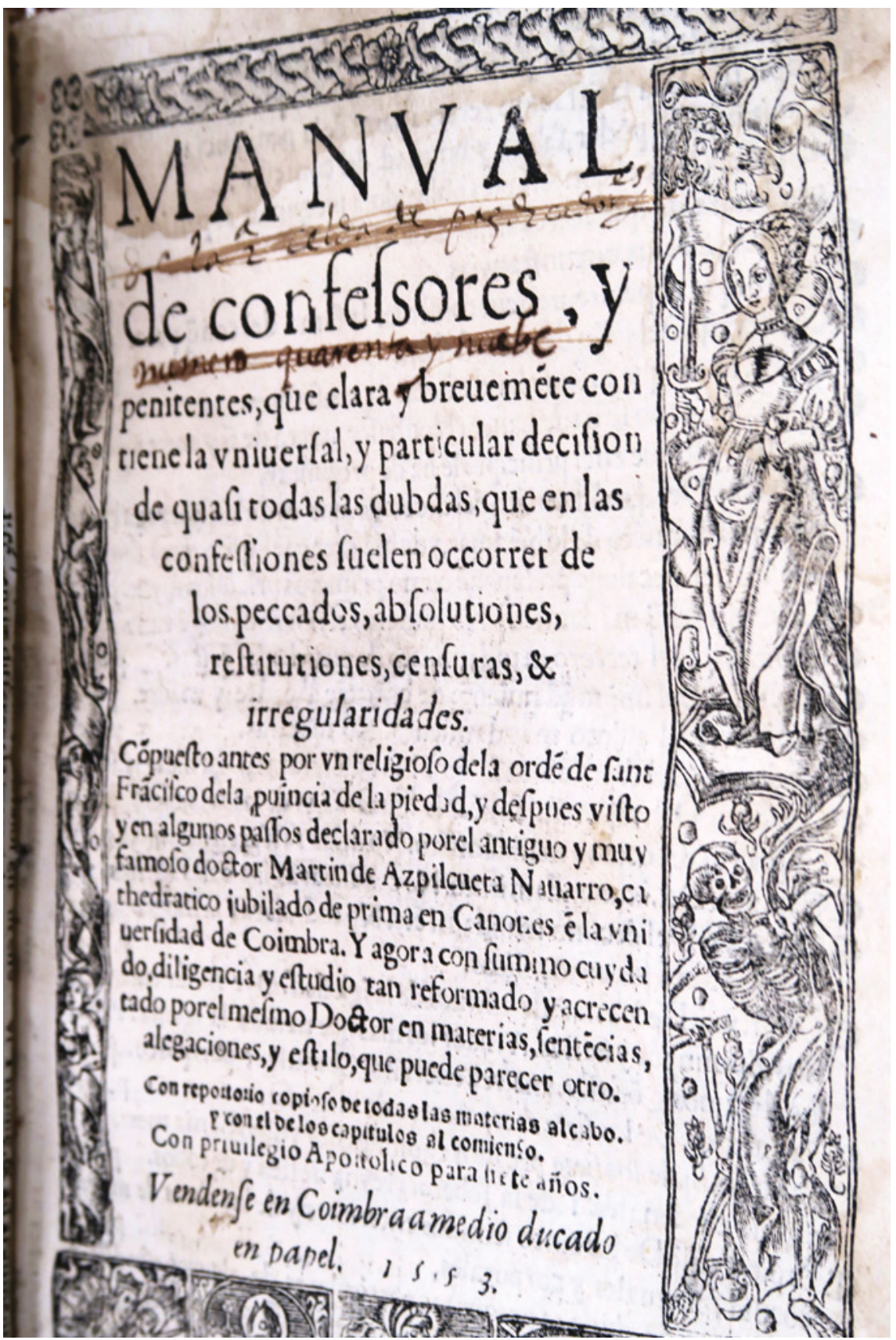

FIGURE 3.2 Martín de Azpilcueta, Manual de confessores y penitentes, Coimbra 1553: Ioannes Barrerius \& Ioannes Alvarez (Biblioteca de la Universidad de Sevilla) PHOTO: OTTO DANWERTH 
three languages after the celebration of the Third Provincial Council of Lima (1582-1583) - which was the first book to have left a South American printing press. ${ }^{46}$ In contrast, the catecismos and the Directorio de Confesores y Penitentes written in the course of the Third Provincial Council of Mexico (1585) were not published at that time; while the first were included in the catechetical works of the Fourth Mexican Council only in 1771, the latter even awaited its edition for more than four centuries. ${ }^{47}$

Scholars have counted that more than $31 \%$ of the books printed in New Spain were written in indigenous languages during the 16th century. Over the course of the 17th century, this ratio changed profoundly and comprised only about $3 \%$ of the locally produced books. ${ }^{48}$

\subsection{Possessing Books in Colonial Spanish America}

Up to this point the - European or American - origins of books circulating in Spanish America have been dealt with. Once they had arrived in the New World, most of the books were distributed by merchants, who delivered them to their clients (for example, religious orders), sold them in bookshops, or sent them to local regions via "economic agents". 49 The American market was so profitable that book catalogues were printed for certain regions in order to promote the book sales there..$^{50}$

In order to know more about the dissemination of the printed works there, one relies on other sources, e.g., inventories of goods owned by individuals. These lists were included in notarial documentation for the living as well as for the dead. Two relevant sets of sources are wills and lists of bienes de difuntos, i.e., "goods of the deceased" (who had passed away in Spanish America without

46 Doctrina christiana, y catecismo para instruccion de los indios, y de las demas personas, que han de ser enseñadas en nuestra sancta fé, Lima 1584: Antonio Ricardo. See Saranyana (ed.), Teología en América Latina, vol. 1, 74-78; Durán, Monumenta catechética hispanoamericana, vol. 2, 331-741.

47 See Osvaldo Moutin (Chapter 8) in this volume; Saranyana (ed.), Teología en América Latina, vol. 1, 192-203; Durán, Monumenta catechética hispanoamericana, vol. 3, 135578; Poole (ed.): The Directory for Confessors 1585.

48 Chocano Mena, "Colonial Printing and Metropolitan Books", 73; see Calvo, "The politics of print", 279. - Recent monographs on book censorship and Inquisition in American tribunals include: Guibovich Pérez, Censura, libros e Inquisición en el Perú colonial; Nesvig, Ideology and Inquisition; Ramos Soriano, Los delincuentes de papel; Campillo Pardo, Censura, expurgo y control en la biblioteca colonial neogranadina.

49 González Sánchez, New World Literacy, 143.

50 See Rueda Ramírez, "El derecho en los catálogos de venta de los libreros sevillanos". 
heirs).${ }^{51}$ Books could be sold or given as gifts during one's lifetime, or sold in an auction after death. These second-hand sales were a good opportunity to buy books at lower prices. Little is known so far about these transactions, which are important for understanding the circulation of books in the American regions; the best information is provided in notarial records.

The circulation of (religious) pragmatic texts contributed to the establishment of knowledge regimes in early modern Hispanic America. Manuals of moral theology, catechisms, and other genres applied above all in missionary contexts were central media for the diffusion of normative orders in an emerging empire. In order to evaluate their distribution in different regions during the 16th and 17th centuries, a vast multidisciplinary bibliography on the production, possession, and circulation of books has been established. ${ }^{52}$

Which types of pragmatic literature can be detected in personal and institutional libraries, ${ }^{53}$ and what do we know about the circulation of these resources? Whereas the research on the book possession of bishops, friars and priests, of colonial authorities, and of wealthy settlers offers rich material, the investigation on book collections of institutions and corporations - such as cathedral chapters, monasteries of mendicant orders, Jesuit colleges, the Inquisition as well as parishes - is not that advanced but catching up, as some chapters of this volume show. In particular, library catalogues of institutions and personal book inventories are central sources to grasp the importance of circulating 'pragmatic' normative books for the creation of knowledge structures - especially missionary ones - in imperial contexts of early colonial America.

\section{Presence of Pragmatic Books in Spanish America: Some Case} Studies

In the final part of this chapter, instead of treating institutional book collections, I would like to present some examples of individuals or pertinent professional groups, who kept pragmatic books in Spanish America.

$5^{1} \quad$ On the topic of this paragraph, see González Sánchez, New World Literacy, 37-39; and ch. $5,185^{-207 .}$

$5^{2}$ Danwerth, A bibliography on the circulation of books in early modern Ibero-America.

53 From the $17^{\text {th }}$ century onwards, an institutional book collection used to be called 'biblioteca' while the lot of books owned by an individual was often called 'librería'; see Rípodas Ardanaz, "Libros, bibliotecas y lecturas", 256; Carlyon and Guibovich Pérez, "Library [Spain/Spanish America]". 
Some book owners distinguished between "theoretical and practical" authors in their libraries, as did a certain Pedro Zamorano. This "vecino de la ciudad de México, corregidor, alcalde mayor and procurador de la Real Audiencia" stated in 1622: "Item declaro que tengo los libros de derecho canonico y ciuil y de los leyes de partida // y nueua recopilacion y de differentes authores assi theoricos como practicos que valdran treçientos pesos pocos mas o menos [...]".54

Other inventories and book titles explicitly used the term 'práctica' for certain types of literature; at the same time, it is an analytic category. In diverse fields of knowledge, for instance, in geography, navigation, architecture, metallurgy, or medicine, we find books directed at a non-specialised readership, which transmitted knowledge regarding practical application..$^{55}$ Thomas Duve, in his introductory chapter (especially section 6), has discussed the relationship between such practical genres and pragmatic literature.

Besides this technical kind of literature, other practical works of a normative nature were published. Manuals and instructions written for the juridical work of lawyers, notaries, and scribes, ${ }^{56}$ using the term 'prácticas' in their titles, were quite common in Spain and in Spanish America. ${ }^{57}$ Let us only mention three well-known examples (in their first editions, followed by many more): Juan Bernardo Díaz de Luco's Practica criminalis canonica, Lyon, Guillermo de Millis, 1543; Gabriel de Monterroso y Alvarado's Práctica civil y criminal \& instrucción de escribanos, Valladolid, Francisco Fernández de Córdoua, 1563; and Blasius Flórez Díez de Mena's Recentiorum practicarum quaestionum iuris canonici, et civilis, ad praxim utrisque fori spectantium libri tres, Medina del Campo, Juan Godínez de Millis, $1603 \cdot{ }^{58}$

54 AGI, México 262, no. 283, fols. $776 \mathrm{r}-779$, here fol. 778 r.

55 To cite but two examples from the late 16 th and early 17 th centuries: Flores, Arte de navegar; García Cavallero, Theorica y practica de la arte de ensaya. - See González Sánchez, "Misión náutica".

56 A classic manual was Yrolo Calar, La política de escrituras (1st ed. México 16o5). - On the literature for scribes and notaries, see Fernández del Castillo, Historia de la escribanía en la Nueva España; Luján Múñoz, "La literatura jurídica notarial en Hispanoamérica durante la colonia"; Herzog, Mediación, archivos y ejercicio; Duve, "Geschichte des Notariats und Notariatsrechts im frühneuzeitlichen Hispanoamerika und im späteren Argentinien”; Burns, Into the Archive; Villalba Pérez and Torné (eds.), El nervio de la República: el oficio de escribano en el Siglo de Oro; Presta, "Redes de tinta y poder"; Rubio Hernández, "Los tratados de práctica notarial en las bibliotecas de escribanos neogranadinos del siglo XVIII".

57 See Luque Talaván, Un universo de opiniones, 140, 252; Rueda Ramírez, "El derecho en los catálogos de venta de los libreros sevillanos”, 467-469. González Sánchez, New World Literacy, 121, defines "prácticas" as "collections of empirical knowledge".

$5^{8}$ On the literary genre 'practica criminalis', see Maihold, Strafe für fremde Schuld?, 7381. A stimulating analysis of 18 th century "forensic practical literature" is Agustín 
In certain cases, authors of "prácticas" explain their motivation for writing their work and thus provide insights into their "methodological" reflections. So did Pedro Pérez Landero Otañez y Castro, who wrote a Practica de visitas y residencias, dealing with how to conduct inspections and judgments of residence at the end of an office-holder's term in Peru. In his preliminary remarks to the reader ("al lector"), he distinguishes the sophisticated knowledge learnt by jurists at "school" from the "experimental knowledge" ("conocimiento experimental") acquired by lawyers during the years when practicing at the bar. It is this very "genre of experimental study" he wants to make accessible to his readers from the juridical and administrative field. ${ }^{59}$

However, we do not focus primarily on such juridical texts but on religious pragmatic literature, which sometimes was labeled 'práctica'60 yet often used other genre titles, such as manual, compendio, suma, sumario, instrucción, indice, guía, regla breve etc. In the following section, we will examine the presence of those pragmatic books in the New World drawing on some case studies.

\subsection{A Sample from Peru in the longue durée $\left(155^{0}-1700\right)$}

A sample from Peru in the longue durée (1550-1700), based on "goods of the deceased" (bienes de difuntos) inventories, allows us to reconstruct the book

Casagrande's contribution (Chapter 11) in this volume; see as well Casagrande, "Literatura Práctica en el siglo XVIII. The use of prácticas in Peru is discussed by Renzo Honores (Chapter 4) in this volume as well as in Honores, "Litigación en la Audiencia Arzobispal de Lima".

59 Pérez Landero Otañez y Castro, Pedro, Practica de visitas y residencias apropriada a los reynos del Perù: "Al letor. No suele ser el mejor Abogado en los estrados el Iurista, que en las Escuelas gano los applausos de mas ingenioso, y sutil; sino el que con muchos años de Abogazia adquirio un conocimiento experimental del modo mas acertado de conducir a feliz expediente los pleytos, y una facilidad, o prontitud erudita, y eloquente para expressar, confirmar, y persuadir el derecho, que patrocina. [...] Para facilitar este genero de estudio experimental, en todas artes se han escrito diuersos libros de practicas, en que los que con mucha fatiga, aplicacion, y desuelo se auentajaron en ellas, deseosos de que su trauajo aliuiase a los que les sucediesen, y que a menos costa, y en menos tiempo aprouechasen mas, dexaron notadas sus obseruaciones, establecido el methodo, que hallaron mas acertado, y con esso superadas grauissimas difficultades, y preuenidos grandes hierros, que sin esta luz se podian facilmente cometer con graue, y a vezes irremediable perjuicio de muchos". I sincerely thank Pedro Rueda for this information and for sharing the quote; he consulted the book in the Biblioteca Universitaria de Salamanca (BG/2791).

6o For example, Vega, Svmma llamada Sylva y Practica del Foro Interior utilissima para Confessores y Penitentes [...]. A pertinent 'bestseller' of the 18th century was Murillo Velarde's Práctica de testamentos (first published in Manila 1745, later in Mexico 1755, 1765 and 179 o, as well as in Madrid 1765 and in Buenos Aires 1792; several editions followed in the 19th century). 
possession of diverse social groups (priests, merchants, artisans, functionaries, miners, et al.). What follows is the statistical evidence for the religious books mentioned in the inventories (715 books, which amount to $30 \%$ of the total number) studied by González Sánchez:61

\section{Types Per cent of religious books}

\begin{tabular}{ll} 
Spiritual & 28 \\
Prayer and liturgy & 23.7 \\
Canon law & 16.4 \\
Moral theology & 12.2 \\
Theology & 11.7 \\
Hagiography & 6.8 \\
Rhetoric & 0.9 \\
\hline
\end{tabular}

Among these religious books, which were possessed by individuals living in the Indies, the percentage of different literary genres resembles those of the book registers known from Seville. The author observes that

$[\ldots]$ the 87 treatises on moral theology are mainly among the possession of the clergy and, exceptionally, among those of four unidentified cases, one doctor, a scribe, and a miner. The fact that these are book manuals used by confessors, work tools of the priestly profession, does not mean they cannot be owned by lay people, no doubt to guide themselves, by reference to the solutions adopted by skilled doctors of theology, during the doubts of conscience arising in their everyday practice (business, vices, behaviour, attitudes, sin, etc.). In any case, it is not my intention to separate rigorously the 'popular' religious books from the professionals $[\ldots] .{ }^{62}$

Among the books and work materials for the priesthood, especially the repertories of moral casuistry, one can - again - identify 'bestsellers', such as Azpilcueta's Compendium and Summary of Confessors and Penitents as well as

61 González Sánchez, New World Literacy, 212.
62 González Sánchez, New World Literacy, 220. 
Summae of Spanish scholastic authors (such as Bartolomé de Medina, Manuel Rodríguez, or Pedro Ciruelo) and certain directories for priests. ${ }^{63}$

Turning to the non-religious books of the sample, it seems that repertories of civil law were more frequently owned by priests than by state functionaries in Peru. These, in sum, possessed only about $18 \%$ of the professional books compared to $82 \%$ of works classified as leisure literature. One could relate this surprising finding to the following Mexican sample, which we have recently studied in the AGI.

\subsection{Inventories of Royal Officials in a Single Year (Mexico, 1622)}

When the newly appointed Mexican viceroy, Diego Carrillo de Mendoza (Marquis of Gelves), took office in 1621, he was to implement a number of reforms. Executing a royal order issued by Philip IV, he asked the Crown officials serving in New Spain to send inventories of their belongings. (In no other American Audiencia was this royal order followed, it seems.) Many royal officials obeyed, as the existence of 1004 inventories in the AGI shows. The documents, all issued in Mexico in a single year (1622), offer insight into the book possession among one specific group: official royal servants, among them high-ranking court officials (oidores), corregidores, alcaldes and public scribes. Less than $4 \%$ of the officials owned registered books, the size of the collection ranging between one item and 920 books. ${ }^{64}$

Here is a transcript of an inventory from a public scribe called García Fernández Cabrera, who was "casado con descendiente de conquistador, vecino y

63 González Sánchez, New World Literacy, 220. - For confession and pertinent manuals in early modern Spain, see Morgada García, "Pecado y confesión en la España Moderna"; Río Parra, Cartografías de la conciencia española en la Edad de Oro; González Polvillo, El gobierno de los otros; González Polvillo, Análisis y repertorio de los tratados y manuales para la confesión en el mundo hispánico; O'Banion, The Sacrament of Penance and Religious Life in Golden Age Spain; Orrego González, La administración de la conciencia. On Portuguese literature, see Correia Fernandes, "Do manual de confessores ao guia de penitentes"; Palomo, "Anaqueles de sacra erudición", 138 (on Azpilcueta). For a comparative analysis of German Catholic and Lutheran manuals in the 'confessional age', see Dürr, "Confession as an Instrument of Church Discipline", 215-240. - Some relevant studies on Spanish America are: Azoulai, Les péchés du nouveau monde; Martínez Ferrer, La penitencia en la primera evangelización de México, 1523-1585; Lira, "Dimensión jurídica de la conciencia”; Roselló Soberón, Así en la tierra como en el cielo; Harrison, Sin and Confession in Colonial Peru. - Concerning manuals for priests, see Saranyana (ed.), Teología en América Latina, vol. 1, cap. XI, 447-479.

64 These legajos (AGI, Audiencia de México, 259-263) were studied as well by Manrique Figueroa: "Bibliotecas de funcionarios reales novohispanos de la primera mitad del siglo XVII". 
escribano público y de cabildo de la villa de San Ildefonso". In 1622, he declared to own the following books:

- la nueba rrecopilacion primera y segunda y terçera parte que costo treynta y dos pesos

- otro libro yntitulado curia filipica que le costo ocho pesos

- otro libro yntitulado notas de diego de rribera que le costo quatro pesos

- otro libro yntitulado platica de monterrosso que le costo çinco pesos

- otro yntitulado torneo que le costo dos pesos y quatro tomines

- otro yntitulado penas de dilictos que le costo un peso y quatro tomines

- otro yntitulado pulitica de yrolo que le costo tres pesos y quatro tomines

- otros dos libros primera y segunda parte de garibay que le costaron nuebe pesos

- otro llamado biaje de jerusalen que le costo un peso

- otra segunda parte de el picaro que le costo dos pesos y quatro tomines //

- otro cuerpo de libro de la segunda parte de la nueba recopilaçion que le costo dose pesos

- otro libro yntitulado farfaro que le costo tres pesos

- unas [h] oras rromanas que le costaron quatro pesos

- dos flosantorus [Flos Sanctorum] de billegas que costaron dies y nuebe pesos ${ }^{65}$

That scribe possessed a small but decent book collection, which in its majority had a professional value, such as legal classic works and manuals for notaries. However, one may note a misspelling in the fourth item: It reads "Platica" (sermon), while it should read "Práctica" de Monterroso.

Moreover, the mentioned inventories include interesting information on book prices in New Spain in comparison to the Old World: Prices for sold books in Mexico were much lower than in Spain, yet prices for new books bought from local Mexican booksellers were three times as high as in Spain. This at least was stated by the high-ranking Dr. Galdós de Valencia ("vecino de la ciudad de México, oidor de la Real Audiencia de México"), who had arrived in New Spain with 30 book boxes and who definitely owned the largest library among his peers there, comprising 920 books. On July 18, 1622 he declared:

Yten ttengo la libreria que adelante yra declarada que fueron mas de ttreinta caxones de libros y q[ue] en esta ciudad [h]a comprado muy pocos despues q. Vino [...] // Todos estos libros truge qu[and]o pase a estas partes escepto muy pocos que he comprado en esta ciudad de Mejico que

65 AGI, México 259, no. 84, fols. 234r-239v, here fol. 235r-v. 
no se pone[n] los precios porq[ue] si se quisiesen vender no se allaria lo que costaro[n] en españa y si se ubiesen de comprar de libreros costarían tres vezes mas. ${ }^{66}$

\subsection{Libraries in Convents and Monasteries}

Turning to pragmatic books held by religious actors and institutions, book collections of convents and monasteries are of special interest. ${ }^{67}$ Dominican friars were present on the Caribbean islands from 1510 and on the American continent from 1526; the first Franciscans arrived in Mexico in 1524, followed by Mercedarians and Augustinians arriving in the 1530s. Later, in 1585, the Carmelites entered the scene. All of these orders established libraries at their American institutions, to a lesser or greater extent (figure 3.3). Books for convents and mission stations were usually ordered by 'comisarios', 'provinciales' or 'procuradores generales' of a particular mendicant order. ${ }^{68}$ The Jesuits, who arrived in the New World in 1572, were in great demand of books, in particular for their educative centres. In Seville they had a representative (a socalled Procurador General de Indias) who was organising the acquisition and transport of books to the American Jesuit colleges. ${ }^{69}$ The books for the church

66 AGI, México 261, no. 84, fols. 213r-226v, here fols. 213v, 220v. - Prices of books in America are discussed by González Sánchez, New World Literacy, 203-207.

67 Various catalogues of these libraries are edited. See, for instance, Mathes, The America's First Academic Library; Osorio Romero, Historia de las bibliotecas novohispanas, 61-118; Rodríguez-Buckingham, "Monastic Libraries and Early Printing in Sixteenth-Century Spanish America"; Llamosas, "Las obras jurídicas en la biblioteca del Colegio Jesuita de Arequipa”; Rey Fajardo, "El papel de las bibliotecas jesuíticas en la fundación de la cultura moderna"; Serrano Prada, Apuntes al catálogo sistemático de la Biblioteca del Colegio de Misiones de Popayán, siglos XV-XVIII. Some relevant literature has already been mentioned above in our historiographic sketch (2.2.). Further references are given in Rueda Ramírez, "El comercio de libros en Latinoamérica colonial", 208-210; Palomo, "Cultura religiosa, comunicación y escritura en el mundo ibérico de la Edad Moderna”, 63-64.

68 This and the following paragraph draw closely upon Rueda Ramírez, Negocio e intercambio cultural, 170-19o. See also Rueda Ramírez, "El abastecimiento de libros de la biblioteca conventual de San Agustín de Puebla de los Ángeles a través de la Carrera de Indias (1609-1613)". For book inventories of Franciscan convents in New Spain, see the two catalogues prepared by Morales, Inventario del Fondo Franciscano, and Morales, "Cómo se formaron las bibliotecas franciscanas". Some examples from Franciscan mission zones in New Spain are discussed by David Rex Galindo (Chapter 9) in this volume. On the acquisition of books for religious communities in Mexico (not only Francisan ones), see García Aguilar, "Para que les den libre paso en todas partes sin que los abran ni detengan'".

69 To mention but one example: For the acquisition of books for the Jesuit Colegio de San Pablo (Lima) and their circulation, see Martín, La conquista intelectual del Perú, chapter 4, 97-120. 


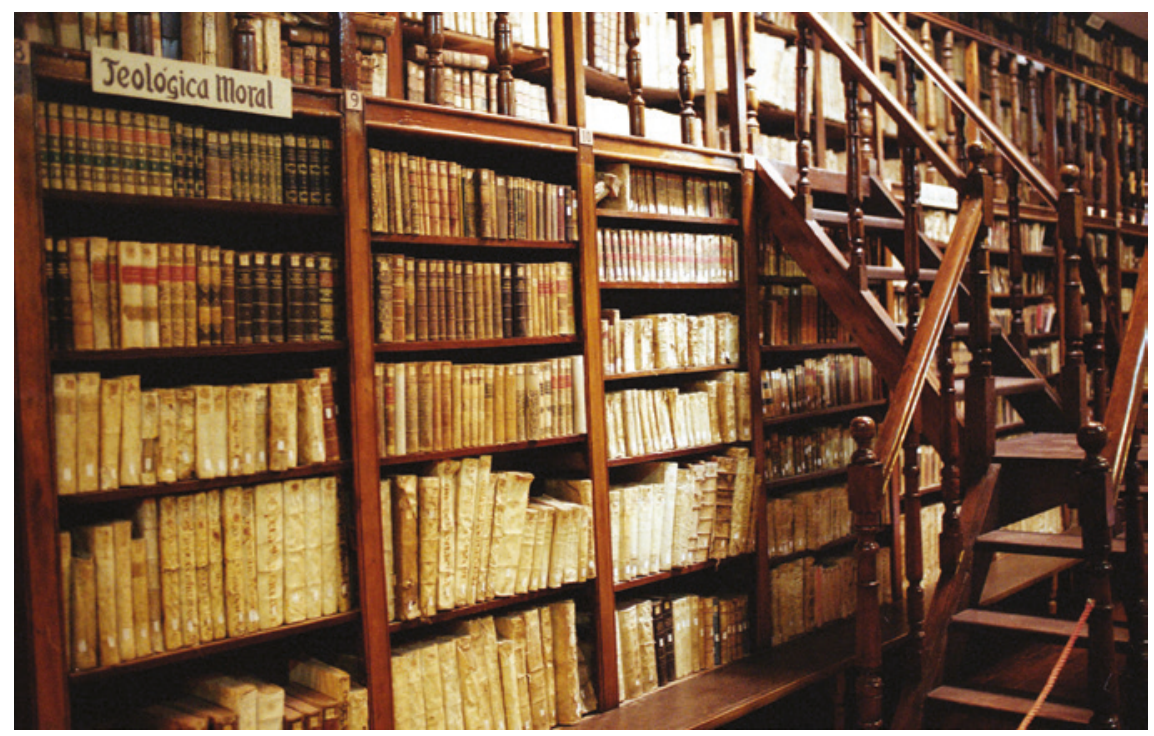

FIGURE 3.3 Library of the Convent La Recoleta, Arequipa PHOTO: OTTO DANWERTH

buildings or diocesan seminars in Spanish America were usually bought or ordered by the ecclesiastical chapters of the pertinent diocese. ${ }^{70}$

Individual clerics, be they friars or secular priests, evidently needed books: for prayer, for devotion, and for their multiple tasks such as the celebration of mass, preaching, or hearing confessions. Before departing to the Indies, they could stock up in Seville on books and religious artifacts offered by local bookshops and artisans. Textiles, clothes, artefacts and works of art were bought and then brought to the New World, as were their personal books. Some orders, such as the Dominicans from 1508 on, expressly permitted friars to carry their own books - a very common practice among secular clerics.

\subsection{Book Possession of Priests}

As to the question of books in the possession of priests, post-Tridentine canon law had created some pertinent norms: The Third Provincial Councils of Lima (1582-1583) and Mexico (1585), as well as numerous South American synods, stipulated that clerics had to own certain types of pragmatic texts. Apart from canon law decrees, priests were supposed to possess pastoral texts (e.g., on the

70 Books on religious normativity used in post-Tridentine seminars for the education of priests are discussed by Peña Espinosa, "Fuentes, autoridades y normas para la enseñanza del derecho canónico en el seminario de Puebla”. 
administration of sacraments), catechetic works, and some treatises on moral theology. ${ }^{71}$ As Magnus Lundberg puts it succinctly, with regard to New Spain:

\begin{abstract}
A priest needed a library. In 1646, Bishop Juan de Palafox y Mendoza wrote that every priest should own a number of books to be able to minister properly and compared a curate without books to a soldier without arms. According to Palafox, the essential priestly library included a Vulgate Bible, a missal, a breviary, a sacramental manual, a copy of the Tridentine decrees as well as some handbooks on moral theology. If working in an indigenous parish, he also needed to have access to grammars, vocabularies and sermon books in relevant languages. ${ }^{72}$
\end{abstract}

Drawn from recent research literature, the following 17th-century examples from different American regions will illustrate that many clerics were lawabiding in this regard.

Based on the investigation of ecclesiastical inspections (visitas), the actual presence of books in the parishes and in doctrina priests' houses can be verified. Research conducted by Pedro Guibovich on the Archbishopric of Lima in the 17th century has identified in this latter category a diversity of works that even in frontier regions were present: compendia of moral theology, penitential summae and manuals, written by authors like Azpilcueta. ${ }^{73}$ The smaller the book formats were - octavo, duodecimo and less - the more convenient they were for everyday use. However, many "manualitos" (a term present in the title of some of these smaller books $)^{74}$ were prone to getting lost over the course of time because of their fragility. ${ }^{75}$

71 Cf. Río Parra, Cartografías de la conciencia española en la Edad de Oro, 191-192.

72 Lundberg: Church Life between the Metropolitan and the Local, 117-118.

73 Guibovich Pérez, "Los libros de los doctrineros en el virreinato del Perú, siglos XVI-XVII". Ibero-American historical research could well profit from integrating scholarship on the Iberian peninsula. For relevant works on Portuguese and Spanish "interior missions" Franciscan and Jesuit ones - see Palomo, "Misioneros, libros y cultura escrita en Portugal y España durante el siglo XVII"; Palomo, "Cultura religiosa, comunicación y escritura en el mundo ibérico de la Edad Moderna".

74 An 18th century example in $24^{\circ}$ (consulted at the John Carter Brown Library) is the anonymous Manualito de las mas usuales bendiciones, que se acostumbran [...], printed in Mexico.

75 A case in point involves the so-called "cartillas", i.e., small-format leaflets used as teaching aids to learn how to read and/or as catechetic tools explaining articles of faith. Although they were printed in the thousands and circulated extensively, only few exist today. See Infantes, "De la cartilla al libro". 
One doctrinero studied by Guibovich was licenciado Agustín Ortiz Cerrano, doctrina priest of Pachacamac, who declared in 1631 to the inspector that he owned the following books:

El concilio de Trento y los concilios limenses de sesenta y siete y ochenta $\mathrm{y}$ tres, $\mathrm{y}$ las sinodales del año trece, $\mathrm{y}$ el cathecismo romano y la suma de Córdova, de Navarro y el Directorium Curatorum, y el Cathecismo y cartilla y sermonario en la lengua quichua y aymara, y un arte y bocabulario en la lengua y exhibió cantidad de sermones assí en la lengua como en romance. ${ }^{76}$

Even more evidence on the book holdings of a particularly infamous priest from the Southern Peruvian region of Andahuaylas has survived in the bienes de difuntos inventories of the AGI, mentioned above (3.1.). In her study of Father Juan Bautista de Albadán, priest of Pampachiri in the first decade of the 17th century, Sabine Hyland dedicates one chapter to his library. ${ }^{77}$ It consisted of 62 volumes - a rather large book collection in comparison to the few books owned in general by other rural priests, mostly had at least a missal and a breviary. Among Albadán's books mentioned by Hyland, we might highlight some pragmatic works. At first, two manuals on penal law are striking: Juan Bernardo Díaz de Luco's Practica criminalis canonica and Juan de Robles' Práctica criminal. With regard to canon law, the priest owned the necessary decrees: those of the Council of Trent as well as those of the Third Provincial Council of Lima; they were accompanied by the "pastoral instruments" produced by the Lima Council, published in 1584 (mentioned above, 2.4). ${ }^{78}$ Somewhat surprising is the lack of diocesan synods.

Hyland's summary on the "after-life" of this priest's library vividly describes the dispersion of his works:

76 Guibovich Pérez, "Los libros de los doctrineros en el virreinato del Perú, siglos XVI-XVII", 108, who quotes the following document: Archivo Arzobispal de Lima, Visitas, leg. 7, exp. 15 .

77 Hyland, The Chankas and the Priest, chapter 4, 54-75, here 6o: "Even the humblest Catholic priest in colonial Apurimac owned at least a missal and a breviary".

78 Hyland, The Chankas and the Priest, 71-72. Actually they were tri-lingual - in Spanish, Quechua and Aymara. - An interesting and somewhat rare work to be found in Peruvian clerical libraries was written by a French Franciscan who had lived in Mexico:Juan Focher, Itinerarium Catholicum, Sevilla 1574. "This work, edited by Focher's native disciple Diego Valadés, describes how to administer the sacraments to indigenous Mexicans; it contains sermons in the native languages [...]". (70). 
After Albadán's death, his goods were auctioned off in Andahuaylas [...]. Forty of his books were sold to the local clergy; the vicar of Andahuaylas, Father Diego Arias de Sotelo, purchased the largest number, including the four volumes by Aquinas, Robles's Práctica criminal and Luco's Practica criminalis canonica [...]. A local priest, Father Gregorio Fernández de Salcedo, purchased the Roman breviary, the Vocabulario eclesiástico, and the three books in Quechua and Spanish: the catechism, the confessional, and the Tercer catecismo. Albadán's successor in Pampachiri, Father Alonso de Sigura, bought a book on the Lima councils and another one on // the Council of Trent [...]. After the sale, twelve volumes, including Horace and Juvenal, remained, and they were packed up and carried to Lima, where they were sold by weight. ${ }^{79}$

In sum, down to the local level, books provided resources of pragmatic normativity, and were amply used by those pragmatici. ${ }^{80}$ Beyond this modern but quite expensive medium, other sources, which were more difficult to grasp yet present in Ibero-America, existed and had a great importance: manuscripts. Manuscript copies or originals of books, called "notebooks by hand" were quite common in the Indies, ${ }^{81}$ as they were in Spain or Portugal. ${ }^{82}$ Frequently, they included transcriptions of didactic works and texts for professional use (small treatises, reports, synods, sermons, etc.); moreover, prohibited works or texts which had not yet been approved of, could circulate in manuscript form. Looking at erudite culture of Mexico in the 17th century, Magdalena Chocano has suggested that it was more the oral transmission and the presence of

79 Hyland, The Chankas and the Priest, 74-75. According to 176 , note 30 , the inventory of his books and other things is found in AGI, Contratación 305B, no. 1, ramo 6, Bienes del difuncto del Padre Juan Bautista Albadán, 1612.

8o Pragmatic religious texts such as sacramental manuals, rituals and confessionaries are central sources for recent studies on the administration of sacraments to the indigenous population. With regard to marriage, see Latasa, "Tridentine Marriage Ritual in Sixteenthto Eighteenth-century Peru"; Zaballa Beascoechea, "Indian Marriage Before and After the Council of Trent".

81 See González Rodríguez, "La difusión manuscrita de ideas en Nueva España (Siglo XVI)"; Tau Anzoátegui, Nuevos Horizontes, 73-75.

82 For the Middle Ages and the Renaissance, see Johnston and van Dussen (eds.), The Medieval Manuscript Book; Richardson, Manuscript Culture in Renaissance Italy; Neddermeyer, Von der Handschrift zum gedruckten Buch. For early modern manuscript culture and circulation in the Iberian world, see Bouza Alvarez, Corre manuscrito; Bouza, Hétérographies; Castillo Gómez, Entre la pluma y la pared; Palomo, "Misioneros, libros y cultura escrita", 142-143; Palomo, "Written empires". 
manuscripts than the written culture that proved decisive for the circulation of ideas..$^{83}$

Magnus Lundberg's research on sacramental manuals for priests - a genre he labels "clerical vademecum" - in mid-colonial New Spain is a case in point. He has shown that a great diversity of those "manuales sacramentales" existed in Mexican dioceses such as Puebla. Particularly in the 163os and 1640s, secular clerics prepared and wrote such pragmatic texts themselves, as they needed them for the ministry of their Nahuatl and Mazahua-speaking parishioners. ${ }^{84}$ These works, which described the priest's work, mainly remained unpublished and circulated in manuscript form:

In the parish ministry, the priests used the small books they had access to and the linguistic diversity of many parishes meant that curates often had to make recourse to their memory, their own manuscripts or manuscripts that had been compiled by colleagues and circulated. ${ }^{85}$

\subsection{The Use of Books - an Open Question}

Coming to a close, I would like to briefly mention the last aspect of book circulation, which is still - and to a large degree - an open question: the use of pragmatic books and the "focus on the reader as the main performer of every process of reception or creative appropriation of a text in a different context". 86

The problem of reading (as well as the oral participation of the illiterate as listeners) is one of the most difficult tasks to tackle. Nevertheless, it is on our agenda, especially as regards the use of pragmatic books owned by clergy

83 Chocano Mena, "Colonial Printing and Metropolitan Books", go; see Calvo, "The politics of print", 279 .

84 Lundberg: Church Life between the Metropolitan and the Local, 117-144. Examples are the Spanish-Nahuatl Manual Mexicano de la administración de los santos sacramentos, conforme al Manual Toledano, by Francisco Lorra Baquio (printed in Mexico 1634), or the Doctrina y Enseñanza of Náguera Yanguas.

85 Lundberg: Church Life between the Metropolitan and the Local, 143-144; see as well 237. For 18 th century Mexico, see Taylor, Magistrates of the Sacred, especially 152-162.

86 Beck, "The Diffusion of Law Books in Early Modern Europe", 201. On the topic of reading, see the rich literature about the Iberian peninsula, for instance, Dadson, Libros, lectores $y$ lecturas; Castillo Gómez (ed.), Libro y lectura en la península ibérica y América (siglos XIII $a X V I I I)$; Prieto Bernabé, Lecturas y lectores; Nalle, "Printing and reading popular religious texts in sixteenth-century Spain"; Palomo, "Cultura religiosa, comunicación y escritura en el mundo ibérico de la Edad Moderna", 85-87; as well as the reflections of Rueda Ramírez, "El comercio de libros en Latinoamérica colonial", 203-205. 


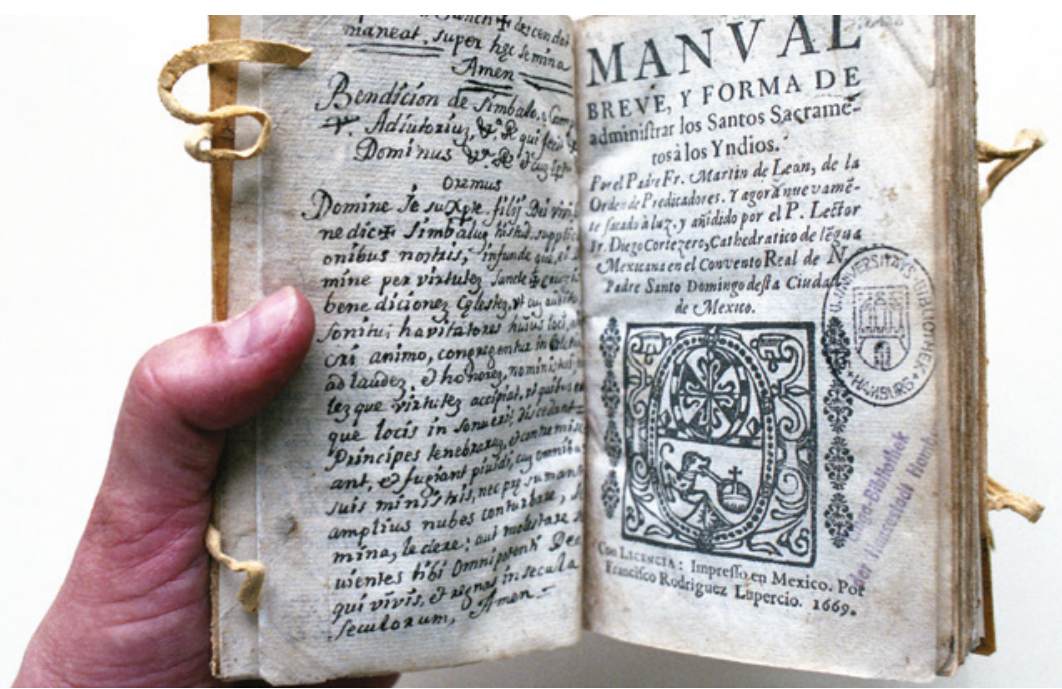

FIGURE 3.4 Martín de León, Manual Breve, y Forma de administrar los Santos Sacramentos à los Indios, México 1669: Rodriguez Lupercio, with manuscript notes (Linga Library, Hamburg) PHOTO: OTTO DANWERTH

and friars. One way of answering this question might be provided by studying the personal aspect of reading: ${ }^{87}$ examining traces that users left in concrete books, like manuscript notes or glosses. Some of these were detected in select works from the Linga Library, Hamburg, from the John Carter Brown Library, Providence, or from Mexican colonial libraries in Mexico City, Puebla, Oaxaca and Guadalajara - all of them recently consulted (figure 3.4). ${ }^{88}$

Let us end, however, with one example of how some Spanish clerics were suspicious of those indigenous people who knew how to read and write Spanish, so-called ladinos. Bartolomé Alvarez, a parish priest from the Audiencia of Charcas (Alto Perú), complained in his in memorial to the King (1588) about their lack of Catholic religion:

87 The personal aspect of reading is stressed by Tau Anzoátegui, Nuevos Horizontes, 78-79; Rípodas Ardanaz, "Libros, bibliotecas y lecturas"; Navarro Bonilla, "Las huellas de la lectura"; and Hespanha, "Form and content in early modern legal books".

88 To mention but one interesting example with manuscript notes (from the Linga Library, Hamburg): León, Manual Breve, y Forma de administrar los Santos Sacramentos à los Indios, printed in México in 1669. A select number of those books is available at the Digital Library De Indiarum Iure, provided by the Max Planck Institute for European Legal History (https://dlc.mpdl.mpg.de/dlc/collection/escidoc:71437). 
Among the virtues that the ladinos pursue is that of bringing a suit and making a petition to lodge an accusation: with this aim, a ladino Indian of Andamarca [...] bought a Monterroso, and in another town called Corquemarca another ladino bought the Partidas of King Alfonso; and this without knowing a word of the Christian doctrine. ${ }^{89}$

This example shows that classic Castilian legal compilations, such as the Siete Partidas as well as a typical pragmatic manual like Gabriel de Monterroso y Alvarado's Práctica civily criminal \& instrucción de escribanos, were circulating and being consulted by indigenous individuals in the Andean highlands to prepare legal litigation against Spanish officials. ${ }^{90}$

Indians, and not only Spaniards, drew on this resource of normativity, which due to the circulation of books was quite accessible in the New World. How this ambivalent resource was used, however, depended on the colonial actors.

\section{Concluding Remarks}

Some preliminary results can be drawn from this brief overview on central characteristics of book circulation in Spanish America, and from some case studies of pragmatic books in colonial contexts.

In the first place, the knowledge regime which aimed to strictly control the circulation of books across the Atlantic and in Spanish America, was based on the work carried out by the House of Trade and the Inquisition. Despite the rigid politics of vigilance, the regime became 'permeable' in some aspects. Books were considered an ambivalent resource, offering useful or dangerous knowledge.

The rich historiography on book circulation in Spanish America provides case studies from a variety of disciplines. These studies are based in part on

89 Alvarez, De las costumbres y conversión de los indios del Perú, 269; cited from the translation in González Sánchez, New World Literacy, 45.

9o See Renzo Honores' contribution in this volume (Chapter 4); as well as Puente Luna and Honores, "Guardianes de la real justicia: alcaldes de indios, costumbre y justicia local en Huarochirí colonial". This innovative case study analyzes the circulation and appropriation of legal knowledge by indigenous alcaldes using Castilian judicial practices - and pragmatic literature - in the colonial Andes. Another telling study, drawing on 18th century cases from Northern New Spain, is Cutter, "El imperio 'no letrado'". - For further insightful studies from New Spain and Peru, see Ramos and Yannakakis (eds.), Indigenous Intellectuals. The last chapter deals with indigenous notaries and discusses Guaman Poma's illustration depicted on the cover of the present volume; see Burns, "Making Indigenous Archives". 
early modern library catalogues, on lists of bought books, on sources stemming from import controls and censorship, as well as on research from book studies and cultural history, providing insight into both the estates of book owners and the book production of the early printing presses in Mexico and Lima.

After an initial analysis of this vast historiography and some archival stays, we find that among the normative resources circulating in Spanish America there was a considerable amount of secular and ecclesiastical pragmatic literature, namely small compendia, summaries of greater moral theological works, and, in part, also of juridical treatises. The books not only reached cities and convents but also rural areas and mission zones.

The circulation of this (religious) pragmatic literature in remote Spanish American regions offered functional resources for establishing a new regime of normativity. How these resources were used in order to implement European normative concepts and codes of conduct in places where 'official' legal sources issued by state authorities were not present, remains to be studied more closely.

Books with a normative content, be they pragmatic or not, cannot be considered as material resources alone. Books and other mediatic forms (manuscripts) refer to immaterial resources - secular and spiritual normativity, morality, knowledge - which are reflected or even embodied in them. This ambivalent potential becomes clear when their use by colonial actors is studied.

Future research on the book circulation in Ibero-America will certainly profit from an intellectual exchange with scholars focusing on similar topics in the Iberian Peninsula, or in other European regions. At the same time, within this field of investigation, legal history and cultural history are encouraged to work together in order to improve our understanding of normative literature genres.

\section{Acknowledgements}

This chapter draws on an earlier article published in Spanish: Danwerth, "La circulación de literatura normativa pragmática en Hispanoamérica (siglos XVI-XVII)". 


\section{Bibliography}

\section{Manuscripts}

Archivo General de Indias, Sevilla (AGI), Contratación 674. AGI, México 259-263.

\section{Printed Sources}

Alvarez, Bartolomé, De las costumbres y conversión de los indios del Perú. Memorial a Felipe II (1588), ed. Martín Rubio, María del Carmen, Madrid 1998.

Díaz de Luco, Juan Bernardo, Practica criminalis canonica, Lyon 1543: Guillermo de Millis.

Díez de Mena, Blasius Flórez, Recentiorum practicarum quaestionum iuris canonici, et civilis, ad praxim utrisque fori spectantium libri tres, Medina del Campo 16o3: Juan Godínez de Millis.

Doctrina christiana, y catecismo para instruccion de los indios, y de las demas personas, que han de ser enseñadas en nuestra sancta fé, Lima 1584: Antonio Ricardo.

Flores, Lázaro de, Arte de navegar. Navegacion astronomica, theorica, y practica. En la qual se contienen tablas nuevas de las declinaciones de el sol [...], [Madrid] 1673: Iulian de Paredes.

García Cavallero, Joseph, Theorica y practica de la arte de ensaya. Oro, plata, yvellon rico [...], Madrid 1713: Agustín Fernández.

Manualito de las mas usuales bendiciones, que se acostumbran, con experimentado provecho de sanos, y enfermos [...], Reimpresso en México 1772: Felipe de Zuñiga y Ontiveros.

Molina, Alonso de, Confessionario mayor en lengua Mexicana y Castellana, México, Antonio de Espinosa, 1565 .

Monterroso y Alvarado, Gabriel de, Práctica civil y criminal \& instrucción de escribanos, Valladolid 1563: Francisco Fernández de Córdoua.

Murillo Velarde, Pedro, Práctica de testamentos, Manila 1745: Imprenta de la Compañia de Jesus por D. Nicolas de la Cruz Bagay (later editions: Mexico 1755, 1765 and 179o, as well as Madrid 1765 and Buenos Aires 1792; several editions followed in the 19th century).

Pérez Landero Otañez y Castro, Pedro, Practica de visitas y residencias apropriada a los reynos del Perù y deducida de lo que en ellos se estila, Napoles 1696: por Nicolas Layno.

Recopilación de leyes de los reynos de las Indias, Madrid 1681: Iulian de Paredes.

Vega, Alonso de la, Svmma llamada Sylva y Practica del Foro Interior utilissima para Confessores y Penitentes [...], Alcalá de Henares 1594: Íñiguez de Lequerica.

Veitia Linage, Joseph de, Norte de la Contratación de las Indias occidentales, Buenos Aires 1945 (1st ed. Sevilla 1672: Juan Francisco de Blas). 
Yrolo Calar, Nicolás De, La política de escrituras, ed. de Martínez López-Cano, María del Pilar, México 1996 (1st ed. México 1605: Diego Lopez Daualos).

\section{Literature}

Acosta Rodríguez, Antonio, Adolfo González Rodríguez, Enriqueta Vila Vilar (eds.), La Casa de la Contratación y la navegación entre España y las Indias, Sevilla 2003.

Agnolin, Adone, L'invenzione del Tupi. Imprese coloniali e catechismi indigeni, Bologna 2014.

Argouse, Aude, "De libros y otras cosas: el legado del obispo De la Puebla González. Santiago de Chile, 1705", in Relaciones. Estudios de historia y sociedad (Zamora/ Michoacán) 36, no. 144 (2015), 13-53.

Aspell de Yanzi Ferreira, Marcela, Carlos Alberto Page (eds.), La Biblioteca Jesuítica de la Universidad Nacional de Córdoba, Córdoba 2000.

Ávila Martel, Alamiro de, "La impresión y circulación de libros en el derecho indiano", in Revista Chilena de Historia del Derecho (Santiago de Chile) 11 (1985), 189-209.

Azoulai, Martine, Les péchés du nouveau monde: les manuels pour la confession des Indiens. XVIe-XVIIe siècle, Paris 1993.

Barnadas, Josep M., Bibliotheca Boliviana Antiqva. Impresos coloniales (1534-1825), 2 vols., Sucre 2008.

Barrientos Grandón, Javier, La cultura jurídica en el Reino de Chile. Bibliotecas de ministros de la Real Audiencia de Santiago (s. XVII y XVIII), Santiago de Chile 1992.

Barrientos Grandón, Javier, La cultura jurídica en la Nueva España (Sobre la recepción de la tradición jurídica europea en el virreinato), México 1993.

Beck, Laura, "The Diffusion of Law Books in Early Modern Europe. A Methodological Approach", in Meccarelli, Massimo and María Julia Solla Sastre (eds.), Spatial and Temporal Dimensions for Legal History. Research Experiences and Itineraries, Frankfurt am Main 2016, 195-239.

Benito Moya, Silvano G.A., "Bibliotecas y libros en la cultura universitaria de Córdoba durante los siglos XVII y XVIII”, in Información, cultura y sociedad (INIBI, Buenos Aires) 26 (2012), 13-39.

Bouza Alvarez, Fernando J., Corre manuscrito. Una historia cultural del Siglo de Oro, Madrid 2002.

Bouza, Fernando, Hétérographies. Formes de l'écrit au siècle d'or espagnol, Madrid 2010.

Bravo Lira, Bernardino, "La literatura jurídica indiana en el Barroco", in Revista de Estudios Histórico-Jurídicos (Valparaíso) 10 (1985), 227-268.

Bujanda, J[esús] M[artínez] de, Index de l'Inquisition espagnole 1583, 1584, Sherbrooke/ Geneva 1993 .

Burns, Kathryn, Into the Archive: Writing and Power in Colonial Peru, Durham, NC 2010.

Burns, Kathryn "Making Indigenous Archives: The Quilcaycamayoq in Colonial Cuzco", in Ramos, Gabriela and Yanna Yannakakis (eds.), Indigenous Intellectuals. 
Knowledge, Power, and Colonial Culture in Mexico and the Andes, Durham, NC 2014, 237-26o.

Calvo, Hortensia, "The politics of print: the historiography of the book in early Spanish America", in Book History 6 (2003), 277-305.

Camarinhas, Nuno, "Bibliotecas particulares de magistrados no século XVIII", in Oficina do Inconfidência 6, no. 5 (2009), 13-32.

Campillo Pardo, Alberto José, Censura, expurgo y control en la biblioteca colonial neogranadina. Bogotá 2017.

Carlyon, Jonathan E. and Pedro Guibovich Pérez, "Library [Spain/Spanish America]", in Levy, Evonne and Kenneth Mills (eds.), Lexicon of the Hispanic Baroque. Transatlantic Exchange and Transformation, Austin, TX 2013, 193-199.

Casagrande, Agustín E., "Literatura Práctica en el siglo XVIII. El orden procesal en la historia de la justicia rioplatense", in Revista de Historia del Derecho (Buenos Aires) 49 (2015) (http://www.scielo.org.ar/scielo.php?script=sci_arttext\&pid=S185317842015000100001).

Castañeda, Carmen, Del autor al lector. Historia del libro en México, con la colaboración de Myrna Cortés, México 2002.

Castillo Gómez, Antonio, Entre la pluma y la pared. Una historia social de la escritura en los siglos de oro, Madrid 2006.

Castillo Gómez, Antonio (ed.), Libro y lectura en la península ibérica y América (siglos XIII a XVIII), Salamanca 2003.

Cátedra, Pedro M., María Luisa López-Vidriero (eds.), La memoria de los libros: estudios sobre la historia del escrito y de la lectura en Europa y América, 2 vols., Salamanca 2004.

Cervantes Bello, Francisco Javier (ed.), Libros y Lectores en las sociedades hispanas: España y Nueva España (Siglos XVI-XVIII), Puebla 2016.

Chocano Mena, Magdalena, "Colonial Printing and Metropolitan Books: Printed Texts and the Shaping of Scholarly Culture in New Spain, 1539-1700", in Colonial Latin American Historical Review 6 (1997), 69-9o.

Córdoba-Restrepo, Juan Felipe (ed.), Biblioteca antigua. Circulación y conocimiento, Bogotá 2015 .

Cutter, Charles R., "El imperio 'no letrado': En torno al derecho vulgar de la época colonial", in Palacio, Juan Manuel and Manuela Candioti (eds.), Justicia, política y derechos en América latina, Buenos Aires 2007, 169-180.

Dadson, Trevor J., Libros, lectores y lecturas. Estudios sobre bibliotecas particulares españolas del Siglo de Oro, Madrid 1998.

Danwerth, Otto, "La circulación de literatura normativa pragmática en Hispanoamérica (siglos XVI-XVII)", in Thomas Duve (ed.), Actas del XIX Congreso del Instituto Internacional de Historia del Derecho Indiano:Berlin 2016, Madrid 2017, vol. 1, 359-400.

Danwerth, Otto, Teresa Dittmer, Seto Hardjana, Daniel Hausmann, Nicolas Perreaux, Linda Richter, Christian Schleidler, Frederic Steinfeld, David Weidgenannt: "Resources 
in a Social World", in Amelung, Iwo, Hartmut Leppin and Christian A. Müller (eds.), Discourses of Weakness and Resource Regimes. Trajectories of a New Research Program. Frankfurt am Main 2018, 223-253.

Danwerth, Otto, "A bibliography on the circulation of books in early modern Ibero-America", Max Planck Institute for European Legal History Research Paper Series: subsidia et instrumenta 2020 (http://dx.doi.org/10.2139/ssrn.3520508).

Deylen, Wiebke von, "Buchdruck, kolonialer, in Lateinamerika", in Hiery, Hermann (ed.), Lexikon zur Überseegeschichte, Stuttgart 2015, 135-136.

Dolezalek, Gero, "Libros jurídicos anteriores a 1800 en la Biblioteca de la Universidad Nacional Mayor de San Marcos en Lima. Bases para la formación jurídica de los abogados latinoamericanos del siglo XIX", in Studi Sassaresi, serie III, vol. 5: Diritto romano, codificazioni e unità del sistema giuridico latino-americano, Milano 1981, 491-518.

Durán, Juan Guillermo, Monumenta catechética hispanoamericana (siglos XVI-XVIII), 3 vols., Buenos Aires 1984-2017.

Dürr, Renate, "Confession as an Instrument of Church Discipline: A Study of Catholic and Lutheran Confessional Manuals from the 16th and 17th Centuries", in Müller, Sigrid and Cornelia Schweiger (eds.), Between Creativity and Norm-making:Tensions in the Early Modern Era, Leiden 2013, 215-240.

Duve, Thomas, "Geschichte des Notariats und Notariatsrechts im frühneuzeitlichen Hispanoamerika und im späteren Argentinien”, in Schmoeckel, Mathias and Werner Schubert (eds.), Handbuch zur Geschichte des Notariats der europäischen Tradition, Baden-Baden 2009, 595-619.

Duve, Thomas, "Katholisches Kirchenrecht und Moraltheologie im 16. Jahrhundert: eine globale normative Ordnung im Schatten schwacher Staatlichkeit", in Günther, Klaus and Stefan Kadelbach (eds.), Recht ohne Staat?, Frankfurt am Main 2011, 147-174.

Fernandes, Maria de Lurdes Correia, "Do manual de confessores ao guia de penitentes. Orientações e caminhos da confissão no Portugal pós-Trento”, in Via Spiritus (Porto) 2 (1995), 47-65.

Fernández del Castillo, Bernardo, Historia de la escribanía en la Nueva España y el notariado en México, México 1983.

Fernández del Castillo, Francisco (ed.), Libros y libreros en el siglo XVI, 2nd ed., México 1982 ( $1^{\text {a }}$ ed. México 1911).

Fornet, Ambrosio, El libro en Cuba, siglos XVIIIy XIX, Havana 1994.

Fortich Navarro, Mónica Patricia, Togados y letrados: libros, lecturas y bibliotecas en la formación de los abogados neogranadinos, 1739-1777, Bogotá 2011.

Furlong Cardiff, Guillermo, Bibliotecas argentinas durante la dominación hispánica, Buenos Aires 1944. 
García Aguilar, Idalia, "El conocimiento histórico del libro y la biblioteca novohispanos. Representación de las fuentes originales", in Información, culturay sociedad (Buenos Aires, INIBI) 17 (2007), 69-96.

García Aguilar, Idalia, “'Para que les den libre paso en todas partes sin que los abran ni detengan': Libros para las comunidades religiosas de la Nueva España”, in Cuadernos de Historia Moderna 42:1 (2017), 151-73.

García Aguilar, Idalia and Pedro Rueda Ramírez (eds.), Leer en tiempos de la colonia: imprenta, bibliotecas y lectores en la Nueva España, México 2010.

García Aguilar, Idalia and Pedro Rueda Ramírez (eds.), El libro en circulación en la América colonial: producción, circuitos de distribución y conformación de bibliotecas en los siglos XVI al XVIII, México 2014.

García Icazbalceta, Javier, Bibliografía mexicana del siglo XVI. Catálogo razonado de libros impresos en México de 1539 a 16oo, México 1981 (1st ed.1886).

García-Baquero, Antonio, La Carrera de Indias: Suma de contratación y océano de negocios, Sevilla 1992.

Garone Gravier, "Fuentes para el estudio de la tipografía, la imprenta y el libro antiguo mexicano (1539-1821)", in Pecia Complutense 9, núm. 17 (2012), 59-84.

Gil, Fernando, Primeras "doctrinas" del Nuevo Mundo: estudio histórico-teológico de las obras de fray Juan de Zumárraga (1548), Buenos Aires 1993.

Giurgevich, Luana and Henrique Leitão, Clavis bibliothecarum: Catálogos e inventários de livrarias de instituições religiosas em Portugal até 1834, Lisbon 2016.

González Polvillo, Antonio, Análisis y repertorio de los tratados y manuales para la confesión en el mundo hispánico (ss. XV-XVIII), Huelva 2010.

González Polvillo, Antonio, El gobierno de los otros: confesión y control de la conciencia en la España Moderna, Sevilla 2010.

González Rodríguez, Jaime, "La difusión manuscrita de ideas en Nueva España (Siglo XVI)", in Revista Complutense de Historia de América 18 (1992), 89-116.

González Sánchez, Carlos Alberto, "La cultura del libro en el Virreinato del Perú en tiempos de Felipe II", in Colonial Latin American Review 9:1 (2000), 63-80.

González Sánchez, Carlos Alberto, Atlantes de papel. Adoctrinamiento, creación y tipografía en la Monarquía Hispánica de los siglos XVI y XVII, Barcelona 2008.

González Sánchez, Carlos Alberto, New World Literacy. Writing and Culture across the Atlantic, Lewisburg 2011 (Spanish version: Los mundos del libro. Medios de difusión de la cultura occidental en las Indias de los siglos XVI y XVII, Sevilla 1999).

González Sánchez, Carlos Alberto, "La cultura escrita en el Mundo Atlántico colonial: Brasil y América del norte. Claves historiográficas, retos y perspectivas”, in Revista de Indias LXXIII, no. 259 (2013), 633-662.

González Sánchez, Carlos Alberto, "El comercio de libros entre Europa y América en la Sevilla del siglo XVI: Impresores, libreros y mercaderes", in Colonial Latin American Review 23:3 (2014), 439-465. 
González Sánchez, Carlos Alberto, "Misión náutica. De libros, discursos y prácticas culturales en la Carrera de Indias de los siglos XVI y XVII", in Federico Palomo (ed.), La memoria del mundo: clero, erudición y cultura escrita en el mundo ibérico (siglos XVI-XVIII), Madrid 2014, 71-86.

Greer Johnson, Julie (ed.), The Book in the Americas. The role of books and printing in the development of culture and society in colonial Latin America, Providence, RI 1988.

Griffin, Clive, The Crombergers of Seville. The History of a Printing and Merchant Dynasty, Oxford 1988.

Grover, "The Book and the Conquest: Jesuit Libraries in Colonial Brazil", in Libraries and Culture 28:3, 266-283.

Guedes de Campos, Fernanda Maria, Para se achar facilmente o que se busca: Bibliotecas, catálogos e leitores no ambiente religioso (séc. XVIII), Casal de Cambra 2015.

Guibovich Pérez, Pedro, "The Printing Press in Colonial Peru: Production Process and Literary Categories in Lima, 1584-1699", in Colonial Latin American Review 10:2 (2001), 167-188.

Guibovich Pérez, Pedro, Censura, libros e Inquisición en el Perú colonial, 1570-1754, Sevilla 2003.

Guibovich Pérez, Pedro M., "Los libros de los doctrineros en el virreinato del Perú, siglos XVI-XVII", in Oesterreicher, Wulf and Roland Schmidt-Riese (eds.), Esplendores y miserias de la evangelización de América. Antecedentes europeos y alteridad indígena, Berlin 2010, 97-132.

Hampe Martínez, Teodoro, "Lecturas de un jurista del siglo XVI. La biblioteca del doctor Gregorio González de Cuenca, presidente de la Audiencia de Santo Domingo (1581)", in Anuario de Estudios Americanos 41 (1984), 143-193.

Hampe Martínez, Teodoro, Bibliotecas privadas en el mundo colonial: la difusión de libros e ideas en el virreinato del Perú (siglos XVI-XVII), Frankfurt am Main/Madrid 1996.

Hampe Martínez, Teodoro, “Las bibliotecas virreinales en el Perú y la difusión del saber italiano: el caso del virrey Toledo (1582)", in Cantù, Francesca (ed.), Las Cortes virreinales de la Monarquía española: América e Italia, Roma 2008, 539-555.

Hampe Martínez, Teodoro, "Historiografía del libro en América hispana: un estado de la cuestión”, in García Aguilar, Idalia and Pedro Rueda Ramírez (eds.), Leer en tiempos de la colonia: imprenta, bibliotecas y lectores en la Nueva España, México 2010, $55^{-72}$.

Harrison, Regina, Sin and Confession in Colonial Peru. Spanish-Quechua Penitential Texts, 1560-1650, Austin, TX 2014.

Herzog, Tamar, Mediación, archivos y ejercicio. Los escribanos de Quito (siglo XVII), Frankfurt am Main 1996. 
Hespanha, António Manuel, "Form and content in early modern legal books. Bridging the gap between material bibliography and the history of legal thought", in Rechtsgeschichte - Legal History 12 (2008), 12-50.

Honores, Renzo, "Litigación en la Audiencia Arzobispal de Lima: Abogados y procuradores de causas en la litigación canónica, 1600-1650", in Otto Danwerth, Benedetta Albani and Thomas Duve (eds.), Normatividades e instituciones eclesiásticas en el virreinato del Perú, siglos XVI-XIX, Frankfurt am Main 2019, 69-108 (http://dx.doi. org/10.12946/gplh12).

Hyland, Sabine, The Chankas and the Priest. A Tale of Murder and Exile in Highland Peru, University Park, Pennsylvania, PA 2016.

Inch C., Marcela, "La Biblioteca Potosina de la Compañía de Jesús", in Bibliographica Americana, Revista Interdisciplinaria de Estudios Coloniales (Buenos Aires) 4 (2007), 1-11 (http ://www.bn.gov.ar/media/page/marcela-inch.pdf).

Infantes, Víctor, “De la cartilla al libro”, in Bulletin Hispanique 97:1 (1995), 33-66.

Jiménez, Norah Edith, "Los libros en lenguas indígenas como un género de las imprentas novohispanas entre los siglos XVI y XVII", in Jiménez, Norah Edith and Martina Mantilla Trolle (eds.), Colección de Lenguas Indígenas (Fondos del Tesoro: Biblioteca Pública del Estado de Jalisco "Juan José Arreola”), Guadalajara 2007, 65-117.

Jiménez, Nora E., "Cuentas fallidas, deudas omnipresentes. Los difíciles comienzos del mercado del libro novohispano", in Anuario de Estudios Americanos 71:2 (2014), 423-446.

Johnston, Michael and Michael Van Dussen (eds.), The Medieval Manuscript Book: Cultural Approaches, Cambridge 2016.

Kropfinger von Kügelgen, Helga, Exportación de libros europeos de Sevilla a la Nueva España en el año de 1586, Wiesbaden 1973.

Latasa, Pilar, "Tridentine Marriage Ritual in Sixteenth- to Eighteenth-century Peru: From Global Procedures to American Idiosyncrasies", in Rechtsgeschichte Legal History 27 (2019), 105-121.

Leal, Ildefonso, Librosy bibliotecas en Venezuela colonial (1633-1767), 2 vols., Caracas 1978. Leonard, Irving A., Books of the Brave. Being an account of books and of men in the Spanish Conquest and settlement of the sixteenth-century New World. With a new introduction by Rolena Adorno, Berkeley and Los Angeles 1992 (1st ed. Cambridge, MA 1949).

Lértora Mendoza, Celina A., "Bibliotecas académicas coloniales. Reconstrucción y puesta en valor", in Anuario de Historia de la Iglesia 22 (2013), 259-273.

Lira, Andrés, "Dimensión jurídica de la conciencia. Pecadores y pecados en tres confesionarios de la Nueva España, 1545-1732", in Historia Mexicana 55:4 (2006), 11391178 .

Llamosas, Esteban F., "Las obras jurídicas en la biblioteca del Colegio Jesuita de Arequipa", in Rudimentos legales (Jaén) 3 (2002), 95-159. 
Llamosas, Esteban F., "Probabilismo, probabiliorismo y rigorismo: La teología moral en la enseñanza universitaria y en la praxis judicial de la Córdoba tardocolonial”, in Cuadernos del Instituto Antonio de Nebrija de Estudios sobre la Universidad (Madrid) 14:2 (2011), 281-294.

Lohmann Villena, Guillermo, "Los libros españoles en Indias", in Arbor (Madrid) 2, no. 6 (1944), 221-249.

Luján Múñoz, Jorge, "La literatura jurídica notarial en Hispanoamérica durante la colonia", in Revista Interamericana de Bibliografía 3 (1987), 335-368.

Lundberg, Magnus: Church Life between the Metropolitan and the Local: Parishes, Parishioners, and Parish Priests in Seventeenth-Century Mexico. Madrid/Frankfurt am Main 2011.

Luque Colombres, Carlos A., "Libros de Derecho en bibliotecas particulares cordobesas (1573-1810)", in Para la Historia de Córdoba, Córdoba 1971, 267-318 (1st ed. 1945 in Cuadernos de Historia, Córdoba, no. IX).

Luque Talaván, Miguel, Un universo de opiniones. La literatura jurídica indiana, Madrid 2003.

Luque Talaván, Miguel, "De los libros surgen las leyes. Aproximación a los fondos jurídicos de las bibliotecas particulares y públicas novohispanas", in García Aguilar, Idalia (ed.), Complejidad y materialidad: reflexiones del seminario del libro antiguo, México 2009, 65-191.

Maeder, Ernesto J.A., "Libros, bibliotecas, control de lecturas e imprentas rioplatenses en los siglos XVI al XVIII", in Revista Teología (Buenos Aires) 40, no. 77 (2001), $5^{-24 .}$

Maihold, Harald, Strafe für fremde Schuld? Die Systematisierung des Strafbegriffs in der Spanischen Spätscholastik und Naturrechtslehre, Köln 2005.

Maillard Alvarez, Natalia, "Aproximación a la creación de las redes de distribución de libros en América a través de las fuentes españolas (segunda mitad del siglo XVI)", in Anuario de Estudios Americanos 71:2 (2014), 479-503.

Maillard Alvarez, Natalia (ed.), Books in the Catholic World during the Early Modern Period, Leiden 2014.

Malagón Barceló, Javier, La literatura jurídica española del siglo de oro en la Nueva España. Notas para su estudio, México 1959.

Manrique Figueroa, César, "Bibliotecas de funcionarios reales novohispanos de la primera mitad del siglo XVII", in Boletín del Instituto de Investigaciones Bibliográficas (México) 19 (2014), 57-93.

Maris Fernández, Stella, La imprenta en Hispanoamérica, Madrid 1977.

Martín, Luis, La conquista intelectual del Perú. El Colegio Jesuita de San Pablo, 1568-1767, Barcelona 2001 (1st ed. Fordham 1967).

Martínez Ferrer, Luis, La penitencia en la primera evangelización de México, 1523-1585, México 1998. 
Mathes, W. Michael, The America's First Academic Library: Santa Cruz de Tlatelolco, Sacramento 1985 .

Mathes, W. Michael, "Humanism in Sixteenth and Seventeenth Century Libraries of New Spain", in The Catholic Historical Review 82 (1996), 412-35.

Mayagoitía, Alejandro, "Notas sobre los alegatos impresos novohispanos", in Memoria del X Congreso del Instituto Internacional de Historia del Derecho Indiano, vol. 2, México 1995, 1001-1030.

Medina, José Toribio, Historia de la imprenta en los antiguos dominios españoles de América y Oceanía, 2 vols., Santiago de Chile 1958.

Medina, José Toribio, Biblioteca hispano-americana (1493-1810), 7 vols., 2nd reprint, Amsterdam 1968 (1st ed. Santiago de Chile 1898-1907).

Millares Carlo, Agustín, "Bibliotecas y difusión del libro en Hispanoamérica colonial: intento bibliográfico", in Boletín Histórico (Caracas) 22 (1970), 25-72.

Mohler, Stephen C., "Publishing in colonial Spanish America", in Inter-American Review of Bibliography 28:3 (1978), 259-273.

Molina Jiménez, Iván, El que quiera divertirse: Libros y sociedad en Costa Rica, 1750-1914, San José 1995 .

Moraes, Rubens Borba de: Livros e bibliotecas no Brasil colonial. 2nd ed., Brasília 2006 (1st ed.1979).

Morales, Francisco, Inventario del Fondo Franciscano del Museo de Antropología e Historia de México, vol. 1, con la colaboración de Dorothy Tanck de Estrada, México 1978.

Morales, Francisco, Inventario del Fondo Franciscano del Archivo Histórico de la Biblioteca Nacional de Antropología e Historia, vol. 2, México 2008.

Morales, Francisco, "Cómo se formaron las bibliotecas franciscanas: Una mirada a través de la Biblioteca Franciscana de Cholula", in: Ciencia y Cultura entre dos mundos. Nueva España y Canarias como ejemplos de knowledge in transit (Actas de congreso, San Sebastián de La Gomera, 2 y 4 de abril de 2009), 14 p. (http://www. fundacionorotava.org/media/web/files/page163_o1_Francisco_Morales.pdf).

Morgado García, Arturo, "Pecado y confesión en la España Moderna: Los manuales de confesores”, in Trocadero (Cádiz) 8-9 (1996-1997), 119-148.

Nalle, Sarah T., "Printing and reading popular religious texts in sixteenth-century Spain”, in Lewis, Tom and Francisco J. Sánchez (eds.), Culture and State in Spain, 1550-1850, New York/London 1999, 123-156.

Navarro Bonilla, Diego, "Las huellas de la lectura: marcas y anotaciones manuscritas en impresos de los siglos XVI a XVIII", in Castillo Gómez, Antonio (ed.), Libro y lectura en la península ibérica y América (siglos XIII a XVIII), Salamanca 2003, 243-287.

Nébias Barreto, Herman, "Legal Culture and Argumentation in the Vice-Reign of Peru from the 16th to the 18th centuries", in Clio@Themis, Révue électronique d'histoire du droit 2 (2009) (http://www.cliothemis.com/Legal-Culture-and-Argumentation-in). 
Neddermeyer, Uwe, Von der Handschrift zum gedruckten Buch. Schriftlichkeit und Leseinteresse im Mittelalter und in der frühen Neuzeit. Quantitative und qualitative Aspekte, 2 vols., Wiesbaden 1998.

Nesvig, Martin A., Ideology and Inquisition: The world of the censors in early Mexico, New Haven, CT 2009.

O livro antigo em Portugal e Espanha, séculos XVI-XVIII, in Leituras (Lisboa) 9-10, 2001-2002.

O'Banion, Patrick J., The Sacrament of Penance and Religious Life in Golden Age Spain, College Park, MD 2013.

O'Gorman, Edmundo, "Bibliotecas y librerías coloniales, 1585-1694", in Boletín del Archivo General de la Nación (México) 10:4 (1939), 661-10o6.

Orrego González, Francisco, La administración de la conciencia. Manuales para confesar y tolerancia cultural en tiempos de la Ilustración ibérica. Siglo XVIII. Aranjuez (Madrid) 2017.

Osorio Romero, Ignacio, Historia de las bibliotecas novohispanas, México 1986.

Osvaldo Cutolo, Vicente, "Bibliotecas jurídicas en el Buenos Aires del siglo XVII", in Universidad (Santa Fe) 30 (1955), 105-183.

Palomo, Federico, "Anaqueles de sacra erudición: Libros y lecturas de un predicador jesuita en el Portugal del siglo XVII", in Lusitania Sacra, $2^{\text {a }}$ série, 18 (2006), 117-146.

Palomo, Federico, "Misioneros, libros y cultura escrita en Portugal y España durante el siglo XVII", in Castelnau-L'Estoile, Charlotte de, Marie-Lucie Copete, Aliocha Maldavsky and Ines G. Županov (eds.), Missions d'évangélisation et circulation des savoirs, XVIe-XVIIIe siècle, Madrid 2011, 131-15o.

Palomo, Federico, "Cultura religiosa, comunicación y escritura en el mundo ibérico de la Edad Moderna”, in Serrano Martín, Eliseo (ed.), De la tierra al cielo. Líneas recientes de la investigación en Historia Moderna, Zaragoza 2013, 53-88.

Palomo, Federico, "Written Empires: Franciscans, Texts and the Making of Early Modern Iberian Empires [Editorial]", in Culture \& History Digital Journal 5:2 (2016) (https://doi.org//10.3989/chdj.2016.v5.i2).

Parada, Alejandro E., “Tipología de las bibliotecas Argentinas desde el periodo hispánico hasta 183o: una primera clasificación provisional", in Información, culturay sociedad, (Buenos Aires, INiBi) 9 (2003), 75-94.

Peña Espinosa, Jesús Joel, "Fuentes, autoridades y normas para la enseñanza del derecho canónico en el seminario de Puebla durante la época novohispana”, in Albani, Benedetta, Otto Danwerth and Thomas Duve (eds.), Normatividades e instituciones eclesiásticas en la Nueva España, siglos XVI-XIX, Frankfurt am Main 2018, 51-67 (http://dx.doi.org/10.12946/gplh5).

Peñalver Gómez, Eduardo (ed.), América escrita. Fondos americanistas en bibliotecas universitarias españolas. Exposición bibliográfica conmemorativa de los bicentenarios de las independencias de las repúblicas iberoamericanas, Sevilla 2010. 
Poole, Stafford (ed.): The Directory for Confessors 1585. Implementing the Catholic Reformation in New Spain. With contributions by John F. Schwaller. Norman, OK 2018. Presta, Ana María, "Redes de tinta y poder. Escribanos, clero e indígenas en la ciudad de La Plata, siglos XVI-XVII", in Anuario de estudios bolivianos, archivísticos y bibliográficos (Sucre) 19 (2013), 351-372.

Prieto Bernabé, José Manuel, Lecturas y lectores. La cultura del impreso en el Madrid del Siglo de Oro (1550-1650), Mérida 2004.

Puente Luna, José Carlos de la and Renzo Honores, "Guardianes de la real justicia: alcaldes de indios, costumbre y justicia local en Huarochirí colonial”, in Histórica (Lima) 40:2 (2016), 11-47.

Ramada Curto, Diogo (ed.), Bibliografia da História do Livro em Portugal, séculos $X V$-XIX, Lisboa 2003.

Ramos, Gabriela and Yanna Yannakakis (eds.), Indigenous Intellectuals. Knowledge, Power, and Colonial Culture in Mexico and the Andes, Durham, NC 2014.

Ramos Núñez, Carlos, Ius Commune. Libros y juristas en la Biblioteca de la Recoleta. Siglos XVIy XVII, vol. 1: Catálogo y estudio preliminar, Arequipa 2016.

Ramos Soriano, José Abel, Los delincuentes de papel: Inquisición y libros en la Nueva Espana (1571-1820), México 2011.

Resines Llorente, Luis, Catecismos americanos del siglo XVI, 2 vols., Valladolid 1992.

Rey Fajardo, José del, Las bibliotecas jesuíticas en la Venezuela colonial, 2 vols., Caracas 1999.

Rey Fajardo, José del and Myriam Marín Cortés (eds.), La biblioteca colonial de la Universidad Javeriana comentada, Bogotá 2008.

Rey Fajardo, José del, "El papel de las bibliotecas jesuíticas en la fundación de la cultura moderna", in Bianchini, Paolo, Perla Chinchilla Pawling and Antonella Romano (eds.), De los colegios a las universidades. Los Jesuitas en el ámbito de la educación superior, México 2013, 125-152.

Reyes Gómez, Fermín de los, El libro en España y América. Legislación y censura (siglos $X V-X V I I I), 2$ vols., Madrid 2000.

Richardson, Brian, Manuscript Culture in Renaissance Italy, Cambridge 2014.

Río Parra, Elena del, Cartografías de la conciencia española en la Edad de Oro, México 2008. Rípodas Ardanaz, Daisy, "Bibliotecas privadas de funcionarios de la Real Audiencia de Charcas", in Memoria del II Congreso Venezolano de Historia, vol. 2, Caracas 1975, 499-555.

Rípodas Ardanaz, Daisy, “Libros, bibliotecas y lecturas [cap. 22]”, in Academia Nacional de la Historia (ed.), Nueva Historia de la Nación Argentina, vol. 3, Buenos Aires 1999, 247-279.

Rodrigues, Luiz Fernando Medeiros, “As 'livrarias’ dos Jesuítas no Brasil Colonial, segundo os documentos do Archivum Romano [sic] Societatis Iesu", in Hofmeister Pich, Roberto, Manuel Lázaro Pulido and Alfredo Santiago Culleton (eds.), Ideas 
sin fronteras en los límites de las ideas / Ideias sem fronteiras nos limites das ideias. Scholastica Colonialis: Status Quaestionis, Cáceres 2012, 285-312.

Rodríguez Marín, Francisco, El “Quijote” y don Quijote en América, Madrid 1911.

Rodríguez-Buckingham, Antonio, "Monastic Libraries and Early Printing in SixteenthCentury Spanish America", in Libraries and Culture (Austin) 24:1 (1989), 33-56.

Roselló Soberón, Estela, Así en la tierra como en el cielo: manifestaciones cotidianas de la culpa y el perdón en la Nueva España de los siglos XVIy XVII, México 2006.

Rubio Hernández, Alfonso, "Los tratados de práctica notarial en las bibliotecas de escribanos neogranadinos del siglo XVIII", in Revista Historia Y MEMORIA (Tunja) 13 (2016), 19-46.

Rueda Ramírez, Pedro José, Negocio e intercambio cultural: el comercio de libros con América en la Carrera de Indias (siglo XVII), Sevilla 2005.

Rueda Ramírez, Pedro José, "El comercio de libros en Latinoamérica colonial: aproximación al estado de la cuestión (siglos XVI-XVIII)", in García Aguilar, Idalia (ed.), Complejidad y materialidad: Reflexiones del seminario del libro antiguo, México 2009, 193-279.

Rueda Ramírez, Pedro José, "Libros europeos en Centroamérica en los siglos XVI-XVII", in Yaxkin (Tegucigalpa) 25:2 (2009), 151-192.

Rueda Ramírez, Pedro José, "El abastecimiento de libros de la biblioteca conventual de San Agustín de Puebla de los Ángeles a través de la Carrera de Indias (16o9-1613)", in Estudios de Historia Novohispana 44 (2011), 17-43.

Rueda Ramírez, Pedro (ed.), El libro en circulación en el mundo moderno en España y Latinoamérica, Madrid 2012.

Rueda Ramírez, Pedro (ed.), "Dossier: Circulación y venta de libros en el mundo americano de la edad moderna: de los circuitos atlánticos a los mercados locales”, in Anuario de Estudios Americanos 71:2 (2014), 413-503.

Rueda Ramírez, Pedro, "El derecho en los catálogos de venta de los libreros sevillanos: la circulación de impresos jurídicos en el mundo atlántico (168o-1689)", in Duve, Thomas (ed.), Actas del XIX Congreso del Instituto Internacional de Historia del Derecho Indiano: Berlin 2016, vol. 1, Madrid 2017, 453-474.

Salinas Araneda, Carlos, "Los textos utilizados en la enseñanza del Derecho Canónico en Chile indiano", in Anuario de Historia de la Iglesia 9 (2000), 215-234.

Sánchez Baena, Juan José, "Noticias sobre el mundo del libro en Cuba antes del desarrollo de la imprenta (1525-1763)", in Contrastes. Revista de Historia (Murcia) 9-10 (1994-1997), 181-205.

Saranyana, Josep Ignasi (ed.), Teología en América Latina, vol. 1: Desde los orígenes a la Guerra de Sucesión (1493-1715), Madrid 1999.

Serrano Prada, José María, Apuntes al catálogo sistemático de la Biblioteca del Colegio de Misiones de Popayán, siglos XV-XVIII: historia y evaluación de la colección, Popayán 2016. 
Solano, Francisco de, "Fuentes para la historia cultural: Libros y bibliotecas de la América colonial”, in Pino Díaz, Fermín del (ed.), Ensayos de metodología histórica en el campo americanista, Madrid 1985, 69-84.

Stintzing, Roderich, Geschichte der populären Literatur des römisch-kanonischen Rechts in Deutschland am Ende des fünfzehnten und im Anfang des sechszehnten Jahrhunderts, Leipzig 1867 .

Tau Anzoátegui, Victor, Nuevos Horizontes en el estudio histórico del Derecho Indiano, Buenos Aires 1997.

Tau Anzoátegui, Victor, El Jurista en el Nuevo Mundo. Pensamiento. Doctrina. Mentalidad, Frankfurt am Main 2016.

Taylor, William B., Magistrates of the Sacred: Priests and Parishioners in EighteenthCentury Mexico, Stanford 1996.

Thompson, Laurence Sydney and Hensley Charles Woodbridge, Printing in Colonial Spanish America, Troy/New York 1976.

Torre Revello, José, El libro, la imprenta y el periodismo en América durante la dominación española, Buenos Aires 1940.

Torre Revello, José, "Lecturas indianas (siglos XVI-XVIII)", in Thesaurus (Bogotá) 17 (1962), 1-29.

Vargas Ugarte, Ruben, Impresos peruanos, 6 vols., Lima 1953-1957.

Villalba Pérez, Enrique and Emilio Torné (eds.), El nervio de la República: el oficio de escribano en el Siglo de Oro, Madrid 2010.

Ward, Kenneth C., "Mexico, where they coin money and print books": the Calderón dynasty and the Mexican book trade, 1630-1730, Ph.D. thesis, University of Texas, Austin, TX 2013 .

Wehling, Peter, "Wissensregime”, in Schützeichel, Rainer (ed.), Handbuch Wissenssoziologie und Wissensforschung, Konstanz 2007, 704-712.

Wilkinson, Alexander S. (ed.), Iberian Books: Books published in Spanish or Portuguese or on the Iberian Peninsula before 1601, Leiden 2010.

Wilkinson, Alexander S. and Alejandra Ulla Lorenzo (eds.), Iberian Books, volumes II \& III: Books published in Spain, Portugal or elsewhere in Spanish or Portuguese between 1601 and 1650 , Leiden 2016.

Wilkinson, Alexander and Alejandra Ulla Lorenzo (eds.), A Maturing Market. The Iberian Book in the First Half of the Seventeenth Century, Leiden 2017.

Zaballa Beascoechea, Ana de, "Indian Marriage Before and After the Council of Trent: From pre-Hispanic Marriage to Christian Marriage in New Spain", in Rechtsgeschichte - Legal History 27 (2019), 90-104.

Zulaica Gárate, Román, Los franciscanos y la imprenta en México en el siglo XVI. Estudio bio-bibliográfico, México 1991. 